\title{
MISALLOCATION, PROPERTY RIGHTS, AND ACCESS TO FINANCE: EVIDENCE FROM WITHIN AND ACROSS AFRICA
}

Sebnem Kalemli-Ozcan

Bent E. Sorensen

Working Paper 18030

http://www.nber.org/papers/w18030

\author{
NATIONAL BUREAU OF ECONOMIC RESEARCH \\ 1050 Massachusetts Avenue \\ Cambridge, MA 02138
}

May 2012

This paper is prepared for the NBER-Africa Project. The authors thank the project for support. We thank Sevcan Yesiltas for superb research assistance. We also thank Mary Hallward-Driemeier, Simon Johnson, Marianna Sørensen, and participants at NBER-Africa Project conferences in Cambridge and Zanzibar for comments. The views expressed herein are those of the authors and do not necessarily reflect the views of the National Bureau of Economic Research.

NBER working papers are circulated for discussion and comment purposes. They have not been peerreviewed or been subject to the review by the NBER Board of Directors that accompanies official NBER publications.

(C) 2012 by Sebnem Kalemli-Ozcan and Bent E. Sorensen. All rights reserved. Short sections of text, not to exceed two paragraphs, may be quoted without explicit permission provided that full credit, including $(\odot)$ notice, is given to the source. 
Misallocation, Property Rights, and Access to Finance: Evidence from Within and Across

Africa

Sebnem Kalemli-Ozcan and Bent E. Sorensen

NBER Working Paper No. 18030

May 2012

JEL No. F40,O10

\begin{abstract}
We study capital misallocation within and across 10 African countries using the World Bank Enterprise Surveys. First, we compare the extent of misallocation among firms within countries. We document high variation in firms' marginal product of capital (MPK), implying that countries could produce significantly more with the same aggregate capital stock if capital were allocated optimally. Such variation differs from country to country with some African countries (success stories) closer to developed country benchmarks. Small firms and non-exporters have less access to finance and have higher returns to capital in general. Self reported measures of obstacles to firms' operations suggest access to finance is the most important obstacle: A firm with the worst access to finance has MPK 45 percent higher than a firm with the worst access to finance as a result of low capital per worker. We compare average levels of the MPK across countries, finding evidence that the strength of property rights and the quality of the legal system help explain country-level differences in capital misallocation.
\end{abstract}

Sebnem Kalemli-Ozcan

John F. Kennedy School of Government

Harvard University

79 JFK Street, Mailbox 28

Cambridge, MA 02138

and University of Houston and CEPR

and also NBER

sebnem.kalemli-ozcan@mail.uh.edu

Bent E. Sorensen

Department of Economics

University of Houston

204 McElhinney Hall

Houston, TX 77204

and CEPR

bent.sorensen@mail.uh.edu 


\section{Introduction}

A number of recent studies argue that misallocation of resources across firms is a prime cause of underdevelopment. Standard theory implies that if domestic capital markets are functioning well, the MPK of each firm equals the market interest rate. If firms instead borrow at different interest rates, maybe due to differential access to informal finance or due to political connections, capital is likely to be misallocated and the MPK will differ across firms.

Alfaro, Charlton, and Kanczuk (2008), Banerjee and Duflo (2004), Bartelsman, Haltiwanger, and Scarpetta (2009), Hsieh and Klenow (2009), and Restuccia and Rogerson (2008) provide evidence of misallocation in different countries and show that misallocation of resources can explain up to 60 percent of the aggregate TFP-differences between poor and rich countries. Differential access to credit may not necessarily lead to severe misallocation if firms with higher MPK invest more as Banerjee and Moll (2010) point out. However, in the absence of secure property rights owners may not reinvest profits: Even if the return to investment is high, government officials may grab a large share of earnings, diluting the incentive of owners to reinvest. Johnson, McMillan, and Woodruff (2002) find exactly such behavior in Russia and Ukraine after the breakdown of communism.

We ask two questions in this paper: What is the extent of capital misallocation within African countries, and why does misallocation vary across these countries? We quantify capital misallocation across manufacturing establishments within 10 African countries in 2005 and 2006 using establishment-level data from the World Bank Productivity and Investment Climate Survey. ${ }^{1}$ This is a unique survey undertaken as part of a major World Bank initiative between 1999 and 2007 in 80 developed and developing countries around the world. The main purpose of the survey was to identify obstacles to firm performance and growth; hence the survey not only asks questions on firm characteristics and outcomes but also many questions on the perceived severity of obstacles such as crime, infrastructure, and financing constraints. Having firms' own perceptions of financing constraints is a big advantage of the data set because much of the literature infers financing constraints from companies' financial statements using various modeling and econometric techniques. This data set has been used by, among others, Beck, Demirgüç-Kunt, Laeven, and Maksimovic (2006) and Beck, Demirgüç-Kunt, and Maksimovic (2005), who show that these self-perceived constraints actually bind and hurt firm growth. Our data set has information on small and large, as well as listed and private firms, which allows us to control for some important firm characteristics.

\footnotetext{
${ }^{1}$ Here, "establishment" refers to a production unit which may be part of a larger firm, but for simpler reading we will also use the term "firm."
} 
To the best of our knowledge, there is no systematic study undertaken which calculates the extent of misallocation and its determinants for Africa using comparable firm-level data from many countries.

In the literature, there are various approaches employed for calculating the extent of misallocation of capital across firms within a country. As stated above, one of the advantages of our data set is that it allows us to compare the interest rates firms are paying with the market interest rate. This is our starting point because we have data on the interest rates each firm pays on loans. We show that many firms borrow at rates up to 30-40 percent suggesting that firms have even higher marginal returns to capital. ${ }^{2}$

We calculate the MPK for each firm using firm-level output and capital stocks under the assumption that the production function is Cobb-Douglas (with parameters calibrated from the literature). Doing so reveals that the distribution of the MPK varies a lot within most African countries. This indicates that capital is inefficiently allocated - a fact that cannot be derived from country level aggregate figures. We, next, calculate a measure of misallocation suggested by Hsieh and Klenow (2009) and this measure also indicates imperfect capital and/or labor allocation. ${ }^{3}$

Having calculated the extent of misallocation, we seek to explain firm-level differences in returns to capital within countries and the variation in misallocation across countries. First, we show, using multiple regressions, that firms with less access to finance have higher MPK. Small firms have lower MPK (conditional on access to finance and other regressors), indicating that higher efficiency could be attained by allocating more capital to large firms. Moving from a firm where access to finance is no obstacle to a firm where access to finance is a very severe obstacle increases the MPK by 45 percent, revealing that obstacles to credit have important real effects. Second, we find a clear positive correlation between country-level misallocation and the strength of property rights, measured using expropriation risk and investment profile variables from the International Country Risk Guide (ICRG). These variables help explain the variation in misallocation across African countries consistent with the patterns found by Johnson, McMillan, and Woodruff (2002) for former communist countries.

Hence, we contribute to the recent debate on "what works in Africa?" in the following sense. Once we calculate the extent of misallocation using different methodologies, we can explain the

\footnotetext{
${ }^{2}$ Banerjee (2002) displays similar evidence for other developing countries. He emphasizes that these rates must be the rates that firms actually pay because default is rare.

${ }^{3}$ We attempted a final approach by estimating the correlation between productivity and size; see Alfaro, Charlton, and Kanczuk (2008) and Bartelsman, Haltiwanger, and Scarpetta (2009); however, we did not find any clear patterns.
} 
determinants of this misallocation at the firm level and relate country variation in misallocation to the broader investment climate and business environment. This, in turn, helps us answer why certain countries have better allocation of capital across firms; i.e., we can identify relatively successful countries, such as South Africa and Botswana, relative to unsuccessful ones, such as Ghana and Nigeria, and suggest reasons behind their success.

We use very simple measures of misallocation. In the process of writing the paper, a large amount of measures were considered, using different production function parameters depending on labor and capital type. These more complicated measures produced very noisy patterns and served little purpose. We believe that the lesson from this non-reported work is that fairly underdeveloped economies face many unmeasured obstacles which obscure patterns in anything but simple straightforward measures. ${ }^{4}$ It may be the case that some firms pay higher interest rates due to risk premiums, and it may be the case that the simple functional forms we use to measure the MPK are misspecified, making our measures of misallocation noisy. We therefore compare the statistics calculated for African countries to corresponding statistics calculated for a selection of non-African countries at different levels of development; namely, Germany, Ireland, Spain, South Korea, and India. This comparison reveals that standard deviations across firms of all our misallocation measures are much larger in Africa. For example, the standard deviation of the interest rate is 2-5 times higher in African countries than in European countries and the standard deviation of the MPK is about 40 percent higher in African countries (and in India) than in European countries. More than 50 percent of firms in Africa report that access to finance is a severe obstacle while very few firms in Europe report this as a severe obstacle.

The rest of the paper is structured as follows. Section 2 reports on our field trip to Ghana, a country with a high level of misallocation. Section 3 describes our data in detail while Section 4 presents results from our empirical analysis. Section 5 concludes.

\section{Observations from Investigators' Trip to Ghana}

The authors visited Ghana in May 2011 and interviewed several people familiar with local conditions such as academics and foreign entrepreneurs. Foreign firms are concentrated in Accra, the capital of Ghana, in a free trade zone which has reliable electricity (although many companies in Ghana

\footnotetext{
${ }^{4}$ We studied alternative measures of labor cost (separating full-time, part-time, temporary, and non-production workers), other measures suggested by Hsieh and Klenow (2009), and more narrow indicators of financing constraints such as use of collateral. We also attempted to include both manufacturing and non-manufacturing firms.
} 
rely on generators) and, most importantly, a large modern harbor which allows for easy shipping. Foreign entrepreneurs finance investments with retained earnings or non-local financing because contract enforcement in Africa is weak. Most projects are done with a 50 percent down payment up front. The main attraction by far of investing in Ghana (relative to alternative sub-Saharan countries) is political stability although a reliable local workforce is another plus. It was mentioned that workers from some other African countries are considered less reliable. One multinational corporation located production in Ghana due to local demand for its product from other foreign companies operating in Ghana and sub-Saharan Africa. This corporation was originally shipping its product from an affiliate outside of Africa but could not keep up with the orders - the motivation for shipping from afar was put as: "Nobody wants to buy something made in Africa because quality is perceived to be poor."

Foreign companies have to obey a 70 percent local content requirement which means 70 percent of the workforce should be Ghanaians. This constitutes a problem because the local workforce lacks basic skills; for example, plumbers are hard to find. The companies bring in high-tech personnel from India and the Philippines or from the United States (although Americans sometimes do not want to stay) to train the local workforce. This, however, is costly being very time intensive. Foreign entrepreneurs try to circumvent the 70 percent requirement by other means (one example given was pleading with officials) in order to get things done. Companies import all capital goods and intermediate goods from the United States and other developed countries.

There was general agreement that access to capital through formal channels, such as banks, is severely limited in particular due to lack of clear property rights to land. Being unable to use land as collateral makes it difficult for small businesses to get loans. Micro, informal, loans are often available but annual rates are very high, often above 50 percent. One U.S. multinational company owner said that the main reason, more important than infrastructure, for investing in a factory in the free trade zone was that the land is owned by the government - the company paid for a 47 year lease in advance. Local firms are shut out from financial intermediation and borrow from family or local unofficial lenders. Banks mainly serve the government.

Small scale corruption is another major problem. (Maybe also large scale corruption although we did not learn about that.) Mango producers in the north of Ghana were not able to get fruit to the market in Accra without paying prohibitive bribes at police check points which also slow down trucking on the already inadequate roads (by U.S. standards; according to the foreign entrepreneur, the roads are good by Africa standards). As we understood, police bribes are not particularly large, maybe a few dollars, but with enough checkpoints, it becomes unprofitable to transport low margin 
goods over any substantial distance. In the descriptive statistics tables to be discussed later, we show numbers for Ghana and for African countries pooled.

\section{Data}

\subsection{Productivity and Investment Climate Survey}

The firm-level data comes from the Productivity and Investment Climate Survey of the World Bank, ${ }^{5}$ administered in roughly parallel fashion to enterprizes in 21 countries in Africa, mostly in face-to-face interviews. The data set provides a basis for making country comparisons of investment climate and severity of constraints affecting firms. It captures firms' perceptions of key constraints in the business environment thatg shape operational and investment decisions, as well as several quantitative indices of firm experience.

The first roll-out of surveys was done in 2006 for 13 countries: Burundi, Congo, Botswana, Angola, Guinea Bissau, Guinea Conakry, Namibia, Gambia, Mauritania, Swaziland, Tanzania, Uganda, and Rwanda. In 2007, a second roll-out was conducted in 8 additional countries: South Africa, Mozambique, Zambia, Mali, Ghana, Senegal, Kenya, and Nigeria. Questionnaires of the two roll-outs are not systematically different, except that the second questionnaire generally has more detailed questions. The World Bank also surveys some developed and emerging market countries but the structure of the questionnaires is somewhat different from that used in the African surveys. For comparison with Africa, we choose Germany, India, Ireland, South Korea, and Spain. ${ }^{6}$

The data set for African countries, merging the two roll-outs, has information on 12,752 establishments. For the comparison countries, we have data for 1,196 German, 2,286 Indian, 501 Irish, 598 South Korean, and 606 Spanish establishments. Enterprizes with 5-19, 20-99, and 100+ employees are labeled small, medium sized, and large, respectively.

The Productivity and Investment Climate Survey comprises 4 sets of questionnaires which are particularly designed for the following sectors: Manufacturing, retail, residual (out of manufacturing and retail), and micro (also called the informal sector). Each questionnaire has several sections in which detailed information is given. In related surveys, entrepreneurs provided general information including legal status (e.g., proprietorship); the percentage owned by the largest share holder;

\footnotetext{
${ }^{5}$ The data and related documents are available at http://www.enterprisesurveys.org/

${ }^{6}$ The World Bank also surveys Brazil, China, and Turkey. However, the structure of those surveys is too different from that of the African surveys to allow us to make comparisons.
} 
private, foreign, or government ownership; sex and ethnic origin of the majority owner; level of education and experience of the top manager; when the firm was established; and whether it was formally registered (Section A). The survey also provides information on sales and exports (section C), supplies and import (section D), capacity and innovation (section E), investment climate constraints (section F), infrastructure $(\mathrm{G})$, conflict resolution/legal environment (section $\mathrm{H}$ ), business-government relations (section I), labor regulation (section J), finance (section $\mathrm{K}$ ), and productivity (section L). The data was collected using similar survey sampling methodologies because one of the main objectives in establishing this database is to provide a wide set of measures of firm outcomes and structures which are comparable across countries. The database is mainly a stratified sampling of firms from a representative sample provided by the national statistical offices. If this is not available, stratification is done on a randomly drawn sample. Sample stratification is based on having a third of the data be represented by each size group. Representation of several sectors was also an objective. ${ }^{7}$

\subsection{Questions on Obstacles}

The main question on obstacles is: Do you think the following $(\mathrm{X})$ present any obstacle to the current operations of your establishment? The answers are No Obstacle, Minor Obstacle, Moderate Obstacle, Major Obstacle, and Very Severe Obstacle which are assigned the numerical values $1,2,3,4$, and 5, respectively. We have averaged answers to the question stated above into four groups: Limited Access to Finance, Weak Infrastructure, Weak Law and Order, and Red Tape. Weak Infrastructure is the average of answers to this question where X is "Electricity," "Telecommunications," "Transportation," and "Access to Land." Red Tape is the average of answers to this question where X is "Tax Rates," "Tax Administration," "Customs and Trade Regulations," "Labor Regulations," and "Business Licensing and Permits." Weak Law and Order is the average of answers to this question where $\mathrm{X}$ is "Functioning of the Courts," "Political Instability," "Corruption," "Macroeconomic Instability," "Crime, Theft and Disorder," and "Practices of Competitors in the Informal Sector." Weak Law and Order and Red Tape are coded such that higher values correspond to less law and order and more red tape. For Indian firms, the answers vary between 0 (no obstacle), 1 (minor obstacle), 2 (moderate obstacle), 3 (major obstacle), and 4 (very severe obstacle).

\footnotetext{
${ }^{7}$ The World Bank provides sample selection notes giving detailed information on sampling methodologies for the Enterprise Surveys. Some notes are available at http://www.enterprisesurveys.org/. Details for the Africa sample are available from the authors by request but sample selection notes are not available for Germany, India, Ireland, South Korea, and Spain.
} 


\subsection{Construction of Misallocation Measures}

The variables we use from the Investment Climate Survey are annual interest rates (self reported), sales, capital stock at current replacement cost, labor, total cost of materials and intermediate inputs, total capital income, and total cost of labor. Variables in domestic monetary values are converted into U.S. dollars using the annual exchange rates from World Development Indicators. ${ }^{8}$ The definitions are as follows:

- Annual Nominal Interest Rate $(R)$ : For annual nominal interest rates, we directly use the information on interest rates paid on loans. ${ }^{9}$

- Annual Real Interest Rate: To calculate real interest rates, we subtract inflation of the year the surveys are conducted. The inflation rate, obtained from the International Monetary Fund, is the annual percent change in consumer prices.

- Value added $(Y)$ : Value added is constructed as total sales minus total cost of raw materials and intermediate goods used in production.

- Replacement cost value of Capital Stock $(K)$ : Historical cost of replacing all machinery and equipment with new machines.

- Labor Measure $(L)$ : We use information on the total number of full-time permanent employees at the end of the survey year to proxy labor used in the production process. Permanent employees are defined as all paid employees that work 8 or more hours per day with a contract for a term of one or more fiscal years and/or have a guaranteed renewal of their employment contract.

- Total Cost of Labor $(w L)$ : Includes wages, salaries, bonuses, and social payments.

- Total Capital Income (RK): We multiply the replacement cost of capital (K) with $R$, which is taken as 15\%. Hsieh and Klenow (2009) use a value of $10 \%$ but because the average nominal interest rate for our African sample is about 15\%, we choose this higher value. For our benchmark samples, the average nominal interest rates are given in Table 3 .

\footnotetext{
${ }^{8}$ We noticed that monetary values reported in the domestic currency of Ghana are equal to the ones supposedly converted to U.S. dollars. In order to fix that, we multiplied monetary values in the domestic currency of Ghana by 0.00011, the annual dollar exchange rate of Ghana in 2006.

${ }^{9}$ The question is as follows: Does your establishment currently have a line of credit or loan from a financial institution? If so, what is the average annual interest rate?
} 
Using the above variables, we calculate two measures of misallocation previously used in the literature. We follow Hsieh and Klenow (2009) and outline the pertinent features of their model here.

Assume that aggregate output (or, in Hsieh and Klenow, sectoral output) is a CES index of differentiated outputs of firms $i, i=1, \ldots, M$; i.e., $Y=\left(\sum_{i=1}^{M} Y_{i}^{\frac{\sigma-1}{\sigma}}\right)^{\frac{\sigma}{(\sigma-1)}}$, with the production of each differentiated product given by a Cobb-Douglas production function

$$
Y_{i}=A_{i} K_{i}^{\alpha} L_{i}^{1-\alpha}
$$

where $A_{i}$ is firm-level TFP, $K_{i}$ is capital input, and $L_{i}$ is labor. Profits are

$$
\pi=\left(1-\tau_{y i}\right) P_{i} Y_{i}-w L_{i}-\left(1+\tau_{K i}\right) R K_{i},
$$

where $P_{i}$ is the price of output and $R$ is the rental price of capital. $\tau_{y i}$ is an output distortion, such as a tax on firm $i$ 's output, which does not affect the relative choice of capital and labor. $\tau_{y i}$ is allowed to vary by firm and is intended to capture distortions such as corruption or any other impediment to production of firm $i$ which affects output but isn't tied to capital or labor. $\tau_{K i}$ captures access to credit. A positive value indicates that a firm pays a higher cost of capital than the official interest rate $R$, for example, because the firm only has access to informal credit at high rates. Profit maximization gives price as a markup over marginal cost: $P_{i}=\frac{\sigma}{(\sigma-1)}\left(\frac{R}{\alpha}\right)^{\alpha}\left(\frac{w}{1-\alpha}\right)^{1-\alpha} \frac{\left(1+\tau_{K i}\right)^{\alpha}}{A_{i}\left(1-\tau_{y i}\right)}$. The capital-labor ratio is then

$$
\frac{K_{i}}{L_{i}}=\frac{\alpha}{1-\alpha} \frac{w}{R} \frac{1}{1+\tau_{K i}},
$$

which reflects the relative capital/labor distortion. The marginal revenue product of capital (denoted MRPK) is

$$
\mathrm{MRPK}_{i}=\alpha \frac{\sigma-1}{\sigma} \frac{P_{i} Y_{i}}{K_{i}}=R \frac{1+\tau_{K i}}{1-\tau_{y i}},
$$

which is larger, the larger the output distortion and the larger the capital/labor distortion.

Based on these considerations, we use the following measures of misallocation

1. MPK:

$$
\mathrm{MPK}_{i}=\alpha \frac{P_{i} Y_{i}}{K_{i}}
$$

This measure corresponds to equation (2) for $\sigma=\infty$, the case of perfect competition. The scaling of $P_{i} Y_{i} / K_{i}$ by any constant will not affect our regressions, where we use the logarithm 
of MPK, and affects only the descriptive statistics where we focus on the dispersion, rather than the level, of MPK. Because we don't know what would be a suitable value of $\sigma$ in our sample, we use the perfect competition benchmark.

2. Hsieh and Klenow Measure (HK): For $\alpha=1 / 3$, we calculate the index introduced by Hsieh and Klenow as

$$
\mathrm{HK}_{i}=\frac{\alpha}{1-\alpha} \frac{(w L)_{i}}{R K_{i}}
$$

This measure directly reflects the relative capital distortion because it, under the assumptions of Hsieh and Klenow's model, directly measures $1+\tau_{K i}$ as can be seen from equation (1).

\subsection{Sample Selection Criteria}

In our analysis, we use manufacturing firms and limit ourselves to countries with at least 35 firms having observations on nominal interest rates. Thus, the baseline sample comprises 10 African countries with 4,039 firms, Germany with 221 firms, India with 2,286 firms, Ireland with 175 firms, South Korea with 215 firms, and Spain with 134 firms.

We apply the following sample selection criteria to all firms in the baseline sample:

- We drop firms with missing information on key variables such as value added, capital stock, and labor.

- We drop government-owned firms.

- We drop firms with negative age, which is calculated as the difference of the corresponding year that the firm is surveyed and its date of establishment. Thus, if age is negative, we treat the date of establishment as faulty.

- We drop firms with negative values of sales, capital stock, labor, total cost of raw materials and intermediate goods.

- We drop firms whose replacement cost of capital stock is zero and whose replacement cost is bigger than the net book value of capital.

- We drop firms below the 1 percent and above the 99 percent tails of replacement cost value of capital stock. 
In the final sample, the total number of firms in African countries (Botswana, Burundi, Ghana, Kenya, Nigeria, Senegal, South Africa, Tanzania, Uganda, Zambia) is 3,908. The final sample has 168 German firms, 2,129 Indian firms, 140 Irish firms, 178 South Korean firms, and 114 Spanish firms.

\subsection{Country-Level Data}

Our country-level broad institutional measures come from the ICRG Researchers' Data set and World Bank Doing Business databases.

The first mentioned data set collects political information and financial and economic data, converting these into risk points for each individual risk component on the basis of a consistent pattern of evaluation. The political risk components are "Government Stability," "Socioeconomic Conditions," "Investment Profile," "External Conflict," "Internal Conflict," "Corruption," "Military in Politics," "Religious Tensions," "Weak Law and Order," "Ethnic Tensions," "Democratic Accountability," and "Bureaucracy Quality." The main variables used from this data set are "Corruption" and "Investment Profile."

The second data set provides quantitative measures of regulations regarding starting a business, dealing with construction permits, employing workers, registering property, getting credit, protecting investors, paying taxes, trading across borders, enforcing contracts, and closing a business. The main variable we use from this data set is "Registering Property (days)"

- Registering Property: The number of days it takes to register property that an entrepreneur wants to purchase.

- Corruption: This is a measure that assesses actual or potential corruption in the form of excessive patronage, nepotism, job reservations, "favors-for-favors," and secret party funding. Larger values of the index indicate higher risk of conducting business ineffectively.

- Investment Profile: This is an assessment of factors affecting the risk to investment that are not covered by other political, economic, and financial risk components. The risk rating assigned is the sum of three subcomponents, each with a maximum score of four points and a minimum score of 0 points. A score of 4 points indicates very low risk and a score of 0 indicates very high risk. The subcomponents are "Contract Viability/Expropriation," "Profits," "Repatriation," and "Payment Delays." Larger values of the index indicate higher risk of expropriation, payment delays, etc. 


\section{Empirical Analysis}

\subsection{The Extent of Capital Misallocation}

In Table 1, we display descriptive statistics for our main sample of countries (Burundi, Kenya, South Africa, Senegal, Botswana, Nigeria, Uganda, Ghana, Tanzania, and Zambia). These statistics are calculated for each country and then averaged. We display statistics for Ghana separately andfor comparison to emerging and developing countries - Germany, India, Ireland, South Korea, and Spain. The table displays nominal and real interest rates, the logarithm of the capital-labor ratio, the logarithm of the MPK, and the logarithm of the Hsieh-Klenow HK-index. We choose to show the variables in logarithmic form, where the variables are close to normally distributed, because this is how they are used in the regression analysis.

For the African countries, nominal interest rates have a mean of 15.3 with a standard deviation of 6.1, have minimum and maximum values of 0 and 50, respectively, and exhibit high kurtosis (compared with the value of 3 for the normal distribution). Real interest rates have a mean of 8.7 percent, a standard deviation of 6.2, a minimum of -11.6, and a maximum of 44.4. Inflation rates may differ widely between rural and urban areas and in either event such negative, numerically large, real rates are suspicious, so we will focus on nominal interest rates - see Deaton and Heston (2010) for some issues in measuring price levels in developing countries. It is hard to know what is the optimal level of the interest rate in these countries, but large variation in interest rates indicates suboptimal allocation of capital. Ghana seems fairly similar to other African countries with a large standard deviation of nominal interest rates at 7.3. Szabo (2011) points out that family loans in Ghana are quite common and often carry very small nominal interest rates and combined with the very high interest rates in the informal market pointed out earlier, this helps explain the enormous spread in interest rates. Interest rates display similar large spreads within India (standard deviation of 6.3) while they are much less dispersed, with standard deviations at 2.9 and below, in the developed countries, Germany, Ireland, South Korea, and Spain. This indicates that the large spreads observed in Africa do not reflect actuarially fair risk premiums.

Capital-labor ratios are approximately log-normally distributed with the log-ratio having a kurtosis of about 3 in Africa. If capital is efficiently allocated, all firms have the same MPK but, obviously, our MPK measures are estimated under highly simplifying conditions and therefore

estimated MPKs will vary, maybe due to the simplifying conditions. In order to evaluate if the variation in the MPKs indicates bad allocation of capital we compare to the spread in estimated 
MPKs in developed countries. We find low standard deviations of log-MPK of about 1 in developed countries versus 1.4 for the African sample (1.5 for Ghana) and 1.6 for India indicating misallocation in Africa (and India). The HK-measure takes a theoretical value of unity under efficient allocation and this measure also displays significantly higher variation in Africa and India (due to lack of data, this index is not available for Germany and South Korea).

Table 2 gives a breakdown of the number of firms into exporters, listed, and small firms while Table 3 shows the statistics of Table 1 broken down by type of firm. Large firms have more capital per worker and pay lower interest rates and this holds even more for listed firms. Similarly, exporting and foreign owned firms have more capital relative to labor while foreign owned firms pay slightly lower interest rates. There is also less dispersion of interest rates within the group of listed firms, indicating less misallocation of capital within this group of firms.

We next study these indicators in graphical form where more information can be shown compactly by country. Figure 1(a) displays inflation and the mean and standard deviation of nominal interest rates for South Korea, Spain, Ireland, Germany, Burundi, Kenya, South Africa, Senegal, Botswana, India, Nigeria, Uganda, Ghana, Tanzania, and Zambia in this order where we have ordered the countries by the standard deviation of interest rates from low to high. Among the African countries, Burundi displays the lowest variation in interest rates followed by Kenya and South Africa while Zambia has the highest spread followed by Tanzania, Ghana, and Uganda. Develop countries have much lower variation in interest rates. Figure 1(b) shows box-plots for the distribution of interest rates (albeit with extreme outliers removed). The main "box" of data for each country shows the range of the 25-75 percentiles. Such plots will reveal if the standard deviations are mainly caused by outliers. Visually, if a low interest rate combined with a low 25-75 spread is considered healthy, as we think it should be, Kenya and South Africa (as well as the developed countries) have the best distribution while the distributions of interest rates within Zambia, Nigeria, and Ghana are less good.

Figures 2(a) and (b) display the spread of our two misallocation measures, the MPK and HK indices, respectively. "Spread" is defined as the absolute distance to the country median. Burundi, Botswana, and Nigeria have large spreads in the MPK and, less strongly, in the HK index. The HK-index has very large spreads for Spain and Ireland which indicates that a high spread of this measure may be driven by outliers and, therefore, may not be a good indicator of misallocation.

Figure 3 displays self-reported obstacles to growth for the African countries. Typically, access to finance plays the leading role with over 60 percent of all firms mentioning access to finance as 
a major obstacle in Burundi, Ghana, Nigeria, and Uganda. In South Africa, less than 15 percent of firms mention finance while the number is about 40 percent in Botswana, Kenya, and Tanzania while it is 50 percent in Senegal, and 30 percent in Zambia. Weak infrastructure is typically mentioned by about 30-35 percent of the firms although the number is much lower for Botswana, South Africa, and Zambia. Law and order is a problem for 10-20 percent of firms, although the number is higher in Burundi and Kenya. Finally, red tape is mentioned by about 15-20 percent of firms in most countries with a very low number in South Africa. In Kenya, 35 percent of firms point to red tape-Kenya stands out in these figures as having a significant amount of firms mentioning each of the main obstacles while most other countries have finance dominating other obstacles.

\subsection{Misallocation, Country-Level Institutions, and Investment Climate}

We next turn to the broader policy question of whether good institutions are relevant for performance at the firm level. Our broad institutional variables capture protection of investor rights measured as corruption, the general investment climate, measured as the risk factors affecting the investment and ease of doing business, measured as the days it takes to register a property. These variables are quite correlated among themselves and we show their correlations with the MPK index in Figures 4 and with the HK index in Figure 5.

In Figure 4(a), we see a positive relation between misallocation, measured by average $\log (\mathrm{MPK})$, and registering property. This implies that the longer it takes to register a property, the higher is misallocation. The implication is that informal lending or retained earnings do not make up for the impediments to formal credit. We see a negative slope for the relation between the (countrymean) level of misallocation and the index for investment profile in Figure 4(b). Figure 4(c), which uses an index for corruption on the X-axis, is very similar. This means that countries with a better investment climate (lower expropriation risk/corruption) have lower levels of capital misallocation on average which is consistent with the patterns found by Johnson, McMillan, and Woodruff (2002): Firms are not likely to reinvest profits when property rights (broadly defined) are weak. For example, according to our field study, we would not expect mango producers in Northern Ghana to reinvest profits to increase production for shipping to Accra, because profits would be exhausted by bribes at road check-points. The picture is the same for the HK index, as shown in Figure 5. We proceed with firm-level determinants of the misallocation. 


\subsection{Misallocation and Access to Finance: Firm-Level Evidence}

In this section, we investigate the role of various constraints faced by firms in explaining misallocation. Table 4 gives descriptive statistics for obstacles averaged into four groups: Limited Access to Finance, Weak Infrastructure, Weak Law and Order, and Red Tape as described earlier. Table 4 shows that for African countries and Ghana the most serious obstacle is Limited Access to Finance, which has the highest mean, followed by Weak Infrastructure. Developed countries have lower means in general for all the obstacles. In developed countries, Limited Access to Finance seems to be equivalent to Weak Infrastructure for developing countries in terms of importance of obstacles (India is left out of this table because the answers to the questions are scored on a different scale).

In Table 5, we use OLS-regressions to examine determinants of misallocation using log-MPK as the dependent variable. The MPK is equalized across firms under ideal conditions so in the absence of distortions all regressors should be insignificant and no firm-level obstacle should significantly predict MPK. We interpret positive significant values as determinants of capital market distortions relative to labor market distortions. This is because higher MPK of a firm as a result of a certain obstacle indicates that relatively little capital was allocated to that firm. We find in column (1) that Limited Access to Finance and Weak Infrastructure are insignificantly correlated with distortions, while the MPK is negative and significantly correlated with Weak Law and Order and Red Tape. The coefficient of -9.3 to Weak Law and Order implies that an increase of one unit in Weak Law and Order index (moving from, say, "no obstacle" to "minor obstacle") is associated with a 9.3 percent increase in distortion in the direction of having too much capital relative to labor. I.e., the negative coefficient implies that the MPK is lower when law and order is lacking, indicating that it correlates more with labor market than with capital market distortions - see equation (2).

Column (2) adds industry dummies and column (3) adds age, size, and export status of the firm. Small firms have lower MPKs meaning higher distortions. This implies that aggregate efficiency could be improved by moving capital to larger more efficient firms. Limited Access to Finance now matters for exporting firms; such firms have lower returns and more distortions if their access to finance is limited. Column (4) drops country dummies. The coefficient of Limited Access to Finance becomes significant in column (4), which implies that Limited Access to Finance in particular explains differences in MPK between countries. Limited Access to Finance is not significant for developed countries nor for India, even without the country effects.

Weak Infrastructure is significant when we omit the country dummies in column (4), suggesting 
that this variable in particular explains cross-country differences in MPK. This variable has strong explanatory power for MPK differences within India but is insignificant for Korea and Europe. The coefficient to Weak Infrastructure is positive indicating that firms invest less in physical capital when infrastructure is lacking. The coefficient to Red Tape also is negative in column (4), indicating that cumbersome bureaucracy is important in explaining differences in MPK across African countries as well as within countries (recall that a negative coefficient means lower MPK and so higher distortions). The coefficient to this variable is significantly positive for India and Europe, possibly due to high tax rates and a high degree of bureaucracy discouraging investment although we do not further explore what underlies this. For Africa, the coefficient to Red Tape is negative indicating labor market distortion and it is possible that labor distortions stem from rules such as those imposing minimum numbers of local employees that we described for the case study of Ghanasuch rules would likely be referred to as red tape in the surveys.

As in column (3), when we include interaction terms, we see that the sign for exporting firms interacted with Limited Access to Finance is negative in all columns (not significant for India and positive for Europe). The interpretation of this is that non-exporting firms are relatively highly affected by imperfections in financial markets, leading to high MPKs consistent with such firms having too low a capital/labor ration relative to exporting firms - possibly, exporting firms are able to raise funds through long-term relations with foreign customers. The other interactions are not significant for the African sample on which we focus.

Table 6 repeats the same exercise using the Hsieh-Klenow index. The HK-index takes a high value in the case of capital distortions (too low capital) and a negative value in the case of labor distortions (too little labor compensation). In contrast to the MPK-measure of Table 5, it relies on labor costs being correctly measured. A natural first hypothesis is that imperfect financial markets lead to capital distortions and the estimated coefficient to "Limited Access to Finance" in column (1) confirms this with a very high level of significance. The coefficient indicates that a firm that moves from, say, "no obstacle" to "minor" obstacle, will have 11 percent higher capital distortion (while moving from "no obstacle" to "very severe obstacle" increases capital distortions by 44.4 percent). Red Tape has a negative coefficient, implying that bureaucracy leads to higher labor distortion relative to capital distortions (the opposite holds for India, where capital distortions seems to be more important). In column (4), we see that for exporters, a high value of Limited Access to Finance implies less relative capital distortion compared to non-exporters. Red Tape in particular explains differences between countries as can be seen from the larger coefficient when country dummies are dropped. The interaction effects for exporters reveal negative coefficients, 
meaning for exporters Limited Access to Finance leads to more labor distortions though column (4) suggests this pattern might be driven by country differences.

Overall, the patterns of Table 6 are quite similar to those of Table 5, which indicates that the obstacles we consider distorts capital/labor ratios, rather than output - if output distortions dominated, the regressors would be significant in Table 5 and insignificant in Table 6 and not similar as in our results.

\section{Conclusion}

Using establishment-level survey data from the World Bank, we quantify the extent of misallocation within the manufacturing sector for 10 African countries. To benchmark our results, we use similar data for India, another developing country, and developed countries such as Germany. Our main measures of misallocation are the MPK and an index suggested by Hsieh and Klenow (2009). Both measures reveal a great deal of capital misallocation in Africa and India and little misallocation in developed countries. Within Africa, capital markets appear to function relatively well in South Africa and, a little less so, in Kenya and Burundi, while Nigeria and Ghana display high levels of misallocation.

The firm-level regressions demonstrate that an important determinant of within-country misallocation is Limited Access to Finance. The MPK is 45 percent higher in firms where access to finance is a serious problem compared to firms where access to finance is not a problem. Comparing mean levels of misallocation across countries, we find that countries with higher risk of expropriation; i.e., lower degrees of property right protection, display more misallocation. The within-country firm-level results and across-country results both point to the importance of strong property rights and a well functioning financial system for the efficient allocation of capital. 


\section{References}

Alfaro, L., Charlton A., and Kanczuk F. (2008) "Firm-Size Distribution and Cross-Country Income Differences," NBER Working paper No. 14060.

Bartelsman, E., Haltiwanger, J., and Scarpetta, S. (2009) "Cross Country Differences in Productivity: The Role of Allocation and Selection," NBER Working paper No. 15490.

Banerjee, A. V. (2002) "Contracting Constraints, Credit Markets and Economic Development," MIT Dept. of Economics Working Paper No. 02-17 (Section 4).

Banerjee, A. V. and Duflo, E. (2005) "Growth Theory Through the Lens of Development Economics," in: Aghion, P. and Durlauf, S. (Eds.) Handbook of Economic Growth, Volume 1, 473552. Amsterdam: Elsevier.

Bannerjee, A. V. and Moll, B. (2010) "Why Does Misallocation Persist?" American Economic Journal: Macroeconomics 2, 189-206.

Beck, T., Demirgüç-Kunt, A., Laeven, L., and Maksimovic, V. (2006) "The Determinants of Financing Obstacles," Journal of International Money and Finance 25, 932-952.

Beck, T., Demirgüç-Kunt, A., and Maksimovic, V. (2005) "Financial and Legal Constraints to Growth: Does Size Matter," Journal of Finance 60, 137177.

Deaton, A. and Heston, A. (2010) "Understanding PPPs and PPP based National Accounts," American Economic Journal 2, 1-35.

Hallward-Driemeier, M., Khun-Jush, G., and Pritchett, L. (2010) "Deals versus Rules: Policy Implementation Uncertainty and Why Firms Hate It," NBER Working paper No. 16001.

Hsieh, C. and Klenow, P. (2009) "Misallocation and Manufacturing TFP in China and India," Quarterly Journal of Economics 124, 1403-1448.

Johnson, S., McMillan, J. and Woodruff, C. (2002) "Property Rights and Finance," American Economic Review 92, 1335-1356.

Restuccia, D. and Rogerson, R. (2008) "Policy Distortions and Aggregate Productivity with Heterogeneous Plants, Review of Economic Dynamics 11, 707-720. 
Szabo, Andrea (2011) "Family Financing and Productivity among Small Manufacturing Firms in Ghana," University of Houston, Working Paper. 
Table 1: Descriptive Statistics

Panel A: African Countries, 2005-2006

Obs. Mean Std. Dev. Min Max Median Kurtosis

\begin{tabular}{lrrrrrrr}
\hline Nominal Interest Rate & 811 & 15.3 & 6.1 & 0 & 50 & 14 & 6.6 \\
Real Interest Rate & 811 & 8.7 & 6.2 & -11.6 & 44.4 & 7.7 & 6.3 \\
$\log$ (K/L) & 3538 & 1.5 & 1.8 & -3.7 & 9.1 & 1.5 & 2.8 \\
$\log$ MPK & 3533 & -0.9 & 1.4 & -7.3 & 5.6 & -0.9 & 3.9 \\
$\log$ HK-index & 3539 & 0.2 & 1.5 & -6.3 & 6.1 & 0.3 & 3.4 \\
\hline
\end{tabular}

\begin{tabular}{lrrrrrrr}
\hline Panel B: Ghana, 2006 & & & & & & & \\
& Obs. & Mean & Std. Dev. & Min & Max & Median & Kurtosis \\
\hline Nominal Interest Rate & 52 & 20.5 & 7.3 & 1.5 & 33.3 & 21.1 & 3 \\
Real Interest Rate & 52 & 9.8 & 7.3 & -9.2 & 22.6 & 10.4 & 3 \\
$\log$ (K/L) & 284 & 0.1 & 1.6 & -3.7 & 5.9 & -0.1 & 3.5 \\
$\log$ MPK & 284 & -0.6 & 1.5 & -7.3 & 5.6 & -0.6 & 7.1 \\
$\log$ HK-index & 284 & 0.7 & 1.4 & -6.3 & 5.4 & 0.7 & 6 \\
\hline
\end{tabular}

Panel C: Germany, 2005

Obs. Mean Std. Dev. Min Max Median Kurtosis

\begin{tabular}{|c|c|c|c|c|c|c|c|}
\hline $\begin{array}{l}\text { Nominal Interest Rate } \\
\text { Real Interest Rate }\end{array}$ & $\begin{array}{l}114 \\
114\end{array}$ & $\begin{array}{l}8.5 \\
6.6\end{array}$ & $\begin{array}{l}2.9 \\
2.9\end{array}$ & $\begin{array}{l}4.1 \\
2.2\end{array}$ & $\begin{array}{r}17 \\
15.1\end{array}$ & $\begin{array}{l}7.8 \\
5.9\end{array}$ & $\begin{array}{l}4.2 \\
4.2\end{array}$ \\
\hline $\begin{array}{l}\log (\mathrm{K} / \mathrm{L}) \\
\log \mathrm{MPK}\end{array}$ & $\begin{array}{l}158 \\
155\end{array}$ & $\begin{array}{r}4 \\
-0.7\end{array}$ & $\begin{array}{l}1.1 \\
1.1\end{array}$ & $\begin{array}{r}0 \\
-3.6\end{array}$ & $\begin{array}{l}6.7 \\
2.7\end{array}$ & $\begin{array}{r}4.1 \\
-0.7\end{array}$ & $\begin{array}{r}4.3 \\
4\end{array}$ \\
\hline
\end{tabular}

Panel D: India, 2004

Obs. Mean Std. Dev. Min Max Median Kurtosis

\begin{tabular}{lrrrrrrr}
\hline Nominal Interest Rate & 694 & 12 & 6.3 & 0 & 95 & 11.5 & 94.3 \\
Real Interest Rate & 694 & 8.2 & 6.3 & -3.8 & 91.2 & 7.7 & 94.3 \\
$\log (\mathrm{K} / \mathrm{L})$ & 1495 & 1.3 & 1.5 & -6.4 & 9.3 & 1.4 & 7.1 \\
$\log$ MPK & 1462 & -1.2 & 1.6 & -8.9 & 12.6 & -1.4 & 9.9 \\
$\log$ HK-index & 1481 & -0.2 & 1.9 & -9.2 & 13.7 & -0.2 & 8.6 \\
\hline
\end{tabular}

Table to be continued. 
Table 1 (continued): Descriptive Statistics

Panel E: Ireland, 2005

Obs. Mean Std. Dev. Min Max Median Kurtosis

\begin{tabular}{lrrrrrrr}
\hline Nominal Interest Rate & 96 & 4.7 & 1.6 & 2.7 & 9.5 & 4.2 & 3.5 \\
Real Interest Rate & 96 & 2.3 & 1.6 & 0.3 & 7.1 & 1.8 & 3.5 \\
$\log (\mathrm{K} / \mathrm{L})$ & 132 & 4.4 & 1.1 & 0.2 & 7 & 4.4 & 4.9 \\
$\log$ MPK & 119 & -2.4 & 1.2 & -5 & 2.4 & -2.5 & 6.4 \\
$\log$ HK-index & 131 & 1.4 & 1.2 & -1.6 & 5.3 & 1.5 & 4.4 \\
& & & & & & & \\
\hline
\end{tabular}

Panel F: South Korea, 2005

Obs. Mean Std. Dev. Min Max Median Kurtosis

\begin{tabular}{lrrrrrrr}
\hline Nominal Interest Rate & 106 & 6.4 & 1.5 & 2 & 12 & 6 & 5.6 \\
Real Interest Rate & 106 & 3.6 & 1.5 & -0.8 & 9.2 & 3.2 & 5.6 \\
$\log (\mathrm{K} / \mathrm{L})$ & 152 & 4.3 & 1 & 1.6 & 6.5 & 4.3 & 2.7 \\
$\log$ MPK & 144 & -1 & 1 & -3.8 & 1.9 & -1.1 & 3.7 \\
& & & & & & & \\
\hline
\end{tabular}

Panel G : Spain, 2005

Obs. Mean Std. Dev. Min Max Median Kurtosis

\begin{tabular}{llrrrrrr}
\hline Nominal Interest Rate & 63 & 4.1 & 1.5 & 2.5 & 12 & 3.7 & 12.5 \\
Real Interest Rate & 63 & 0.7 & 1.5 & -0.9 & 8.6 & 0.3 & 12.5 \\
$\log (\mathrm{K} / \mathrm{L})$ & 90 & 4.2 & 1 & 2.1 & 6.8 & 4.2 & 2.5 \\
$\log$ MPK & 88 & -1 & 0.8 & -2.5 & 0.9 & -1.2 & 2.3 \\
$\log$ HK-index & 88 & 1.5 & 0.9 & -0.4 & 3.7 & 1.4 & 2.5 \\
\hline \hline
\end{tabular}

Notes: The nominal interest rate is the response to the question "What is the annual cost of loans (i.e., rate of interest)?" To calculate the real interest rate, we subtract the annual inflation rate (percent change in consumer prices) in the year of the survey. The Marginal Product of Capital (MPK) is calculated as $\alpha \frac{Y}{K}$ where $Y$ and $K$ are value added and replacement cost of capital stock, respectively. The Hsieh-Klenow (HK) index is calculated as $\frac{\alpha}{1-\alpha} \frac{(w L)}{R K}$ where $w L$ and $R K$ stand for total cost of labor and capital, respectively. The standard deviation is calculated for each country and then averaged. The Africa sample comprises Botswana, Burundi, Tanzania, Uganda, Kenya, South Africa, Ghana, Nigeria, Zambia, and Senegal. The firms being surveyed in Germany and South Korea are not asked about the total cost of labor $(w L)$, thus values of the HK-index are not available for those firms. $K / L$ is calculated using the total number of full-time workers at the end of the year of the survey. See the data section for detailed explanations of the variables. 
Table 2: Distribution of Firm Types

\begin{tabular}{|c|c|c|}
\hline \multicolumn{3}{|c|}{ Panel A: African Countries } \\
\hline & $\mathrm{N}$ & $\%$ \\
\hline $\begin{array}{l}\text { All firms } \\
\text { Exporters } \\
\text { Listed } \\
\text { Small }\end{array}$ & $\begin{array}{r}3908 \\
77 \\
22 \\
1998\end{array}$ & $\begin{array}{r}100 \\
1.97 \\
0.56 \\
51.13\end{array}$ \\
\hline \multicolumn{3}{|c|}{ Panel B: Germany } \\
\hline & $\mathrm{N}$ & $\%$ \\
\hline $\begin{array}{l}\text { All firms } \\
\text { Exporters } \\
\text { Listed } \\
\text { Small }\end{array}$ & $\begin{array}{r}168 \\
4 \\
0 \\
53\end{array}$ & $\begin{array}{r}100 \\
2.38 \\
0 \\
31.55\end{array}$ \\
\hline \multicolumn{3}{|c|}{ Panel C: India } \\
\hline $\begin{array}{l}\text { All firms } \\
\text { Exporters } \\
\text { Listed } \\
\text { Small }\end{array}$ & $\begin{array}{r}\mathrm{N} \\
2129 \\
374 \\
127 \\
959\end{array}$ & $\begin{array}{r}\% \\
100 \\
17.57 \\
5.97 \\
45.04\end{array}$ \\
\hline \multicolumn{3}{|c|}{ Panel D: Ireland } \\
\hline $\begin{array}{l}\text { All firms } \\
\text { Exporters } \\
\text { Listed } \\
\text { Small }\end{array}$ & $\begin{array}{r}\mathrm{N} \\
140 \\
16 \\
1 \\
51\end{array}$ & $\begin{array}{r}\% \\
100 \\
11.43 \\
0.71 \\
36.43\end{array}$ \\
\hline \multicolumn{3}{|c|}{ Panel E: South Korea } \\
\hline $\begin{array}{l}\text { All firms } \\
\text { Exporters } \\
\text { Listed } \\
\text { Small }\end{array}$ & $\begin{array}{r}\mathrm{N} \\
178 \\
25 \\
18 \\
53\end{array}$ & $\begin{array}{r}\% \\
100 \\
14.04 \\
10.11 \\
29.78\end{array}$ \\
\hline \multicolumn{3}{|c|}{ Panel F: Spain } \\
\hline & $\mathrm{N}$ & $\%$ \\
\hline $\begin{array}{l}\text { All firms } \\
\text { Exporters } \\
\text { Listed } \\
\text { Small }\end{array}$ & $\begin{array}{r}114 \\
7 \\
0 \\
30\end{array}$ & $\begin{array}{r}100 \\
6.14 \\
0 \\
26.32\end{array}$ \\
\hline
\end{tabular}

Notes: The first column reports the number of firms. The second column reports the percent of firm types. "Exporters" have ratio of exports to total sales above 50 percent. "Listed" firms are listed on a stock exchange. "Small" firms have 5 to 19 employees. The Africa sample comprises Botswana, Burundi, Tanzania, and Uganda, Kenya, South Africa, Ghana, Nigeria, Zambia, and Senegal. 
Table 3: Descriptive Statistics by Firm Types

\begin{tabular}{|c|c|c|c|c|c|c|c|}
\hline Small Firms & Obs. & Mean & Std. Dev. & Min & $\operatorname{Max}$ & Median & Kurtosis \\
\hline $\begin{array}{l}\text { Nominal Interest Rate } \\
\text { Real Interest Rate }\end{array}$ & $\begin{array}{l}217 \\
217\end{array}$ & $\begin{array}{r}16.3 \\
9.9\end{array}$ & $\begin{array}{l}6.9 \\
7.1\end{array}$ & $\begin{array}{r}0 \\
-11.6\end{array}$ & $\begin{array}{r}50 \\
44.4\end{array}$ & $\begin{array}{r}15 \\
9.6\end{array}$ & $\begin{array}{l}7.4 \\
7.5\end{array}$ \\
\hline $\begin{array}{r}\log (\mathrm{K} / \mathrm{L}) \\
\log \mathrm{MPK} \\
\log \mathrm{HK} \text {-index }\end{array}$ & $\begin{array}{l}1985 \\
1984 \\
1985\end{array}$ & $\begin{array}{r}1 \\
-0.8 \\
0.4\end{array}$ & $\begin{array}{l}1.7 \\
1.3 \\
1.4\end{array}$ & $\begin{array}{l}-3.7 \\
-6.1 \\
-6.2\end{array}$ & $\begin{array}{l}9.1 \\
3.5 \\
4.7\end{array}$ & $\begin{array}{r}0.9 \\
-0.8 \\
0.5\end{array}$ & $\begin{array}{r}3 \\
3.3 \\
3.4\end{array}$ \\
\hline Large Firms & Obs. & Mean & Std. Dev. & Min & Max & Median & Kurtosis \\
\hline $\begin{array}{l}\text { Nominal Interest Rate } \\
\text { Real Interest Rate }\end{array}$ & $\begin{array}{l}594 \\
594\end{array}$ & $\begin{array}{r}14.9 \\
8.3\end{array}$ & $\begin{array}{l}5.8 \\
5.9\end{array}$ & $\begin{array}{r}1.5 \\
-9.2\end{array}$ & $\begin{array}{r}38 \\
30.7\end{array}$ & $\begin{array}{r}13 \\
7.7\end{array}$ & $\begin{array}{r}5.5 \\
5\end{array}$ \\
\hline $\begin{array}{r}\log (\mathrm{K} / \mathrm{L}) \\
\log \mathrm{MPK} \\
\log \mathrm{HK} \text {-index }\end{array}$ & $\begin{array}{l}1553 \\
1549 \\
1554\end{array}$ & $\begin{array}{r}2.1 \\
-0.9 \\
0.1\end{array}$ & $\begin{array}{l}1.8 \\
1.5 \\
1.5\end{array}$ & $\begin{array}{l}-3.6 \\
-7.3 \\
-6.3\end{array}$ & $\begin{array}{l}7.9 \\
5.6 \\
6.1\end{array}$ & $\begin{array}{r}2.3 \\
-1 \\
0\end{array}$ & $\begin{array}{l}3.2 \\
4.5 \\
3.7\end{array}$ \\
\hline Listed Firms & Obs. & Mean & Std. Dev. & Min & Max & Median & Kurtosis \\
\hline $\begin{array}{l}\text { Nominal Interest Rate } \\
\text { Real Interest Rate }\end{array}$ & $\begin{array}{l}10 \\
10\end{array}$ & $\begin{array}{r}14.3 \\
5.2\end{array}$ & $\begin{array}{l}4.2 \\
3.4\end{array}$ & $\begin{array}{l}7.5 \\
0.9\end{array}$ & $\begin{array}{l}21.2 \\
10.5\end{array}$ & $\begin{array}{r}14.3 \\
4.6\end{array}$ & $\begin{array}{l}2.3 \\
1.8\end{array}$ \\
\hline $\begin{array}{r}\log (\mathrm{K} / \mathrm{L}) \\
\log \mathrm{MPK} \\
\log \mathrm{HK}-\mathrm{index}\end{array}$ & $\begin{array}{l}22 \\
22 \\
22\end{array}$ & $\begin{array}{r}2.8 \\
-0.9 \\
0.1\end{array}$ & $\begin{array}{r}1.2 \\
1 \\
0.9\end{array}$ & $\begin{array}{r}0.1 \\
-2.5 \\
-1.6\end{array}$ & $\begin{array}{l}4.8 \\
1.4 \\
2.5\end{array}$ & $\begin{array}{r}3.1 \\
-1.1 \\
0\end{array}$ & $\begin{array}{l}2.5 \\
2.9 \\
3.9\end{array}$ \\
\hline Non-Listed Firms & Obs. & Mean & Std. Dev. & Min & Max & Median & Kurtosis \\
\hline $\begin{array}{l}\text { Nominal Interest Rate } \\
\text { Real Interest Rate }\end{array}$ & $\begin{array}{l}801 \\
801\end{array}$ & $\begin{array}{r}15.3 \\
8.8\end{array}$ & $\begin{array}{l}6.1 \\
6.3\end{array}$ & $\begin{array}{r}0 \\
-11.6\end{array}$ & $\begin{array}{r}50 \\
44.4\end{array}$ & $\begin{array}{r}14 \\
7.7\end{array}$ & $\begin{array}{l}6.6 \\
6.3\end{array}$ \\
\hline $\begin{array}{r}\log (\mathrm{K} / \mathrm{L}) \\
\log \mathrm{MPK} \\
\log \mathrm{HK}-\mathrm{index}\end{array}$ & $\begin{array}{l}3516 \\
3511 \\
3517\end{array}$ & $\begin{array}{r}1.5 \\
-0.9 \\
0.3\end{array}$ & $\begin{array}{l}1.8 \\
1.4 \\
1.5\end{array}$ & $\begin{array}{l}-3.7 \\
-7.3 \\
-6.3\end{array}$ & $\begin{array}{l}9.1 \\
5.6 \\
6.1\end{array}$ & $\begin{array}{r}1.5 \\
-0.9 \\
0.3\end{array}$ & $\begin{array}{l}2.8 \\
3.9 \\
3.4\end{array}$ \\
\hline
\end{tabular}

Table to be continued. 
Table 3 (continued): Descriptive Statistics by Firm Types

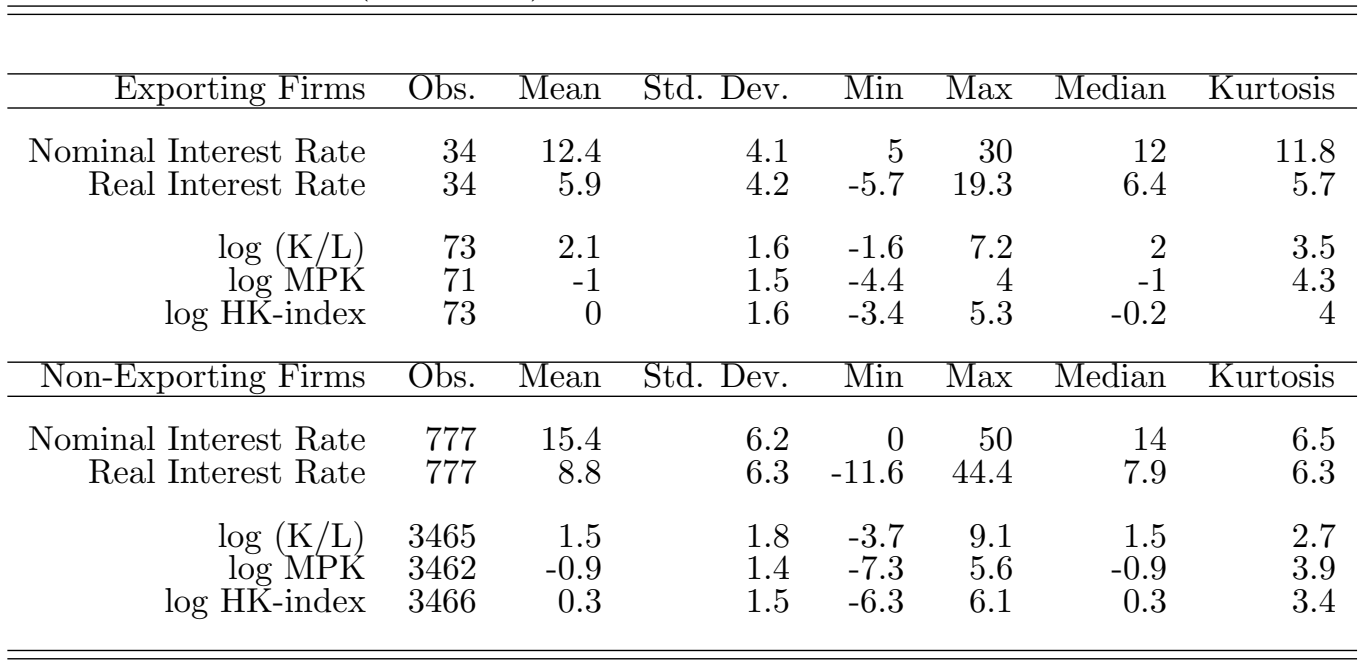

Notes: The sample is for Africa only and comprises Botswana, Burundi, Tanzania, and Uganda, Kenya, South Africa, Ghana, Nigeria, Zambia, and Senegal. See notes to the previous tables for detailed explanations of the variables. 
Table 4: Descriptive Statistics of Obstacles to Firm Operations

\begin{tabular}{|c|c|c|c|c|c|c|c|}
\hline Panel A: African Countries & Obs. & Mean & Std. Dev. & Min & Max & Median & Kurtosis \\
\hline Limited Access to Finance & 3908 & 3 & 1.5 & 1 & 5 & 3 & 1.5 \\
\hline Weak Infrastructure & 3908 & 2.4 & 0.9 & 1 & 5 & 2.5 & 2.4 \\
\hline Weak Law and Order & 3908 & 2.1 & 0.8 & 1 & 5 & 2 & 2.6 \\
\hline Red Tape & 3908 & 2 & 0.8 & 1 & 5 & $1 . \overline{8}$ & 2.9 \\
\hline Panel B: Ghana & Obs. & Mean & Std. Dev. & Min & Max & Median & Kurtosis \\
\hline \multirow{4}{*}{$\begin{array}{r}\text { Limited Access to Finance } \\
\text { Weak Infrastructure } \\
\text { Weak Law and Order } \\
\text { Red Tape }\end{array}$} & 305 & 3.6 & 1.4 & 1 & 5 & 4 & 2.4 \\
\hline & 305 & 2.5 & 0.7 & 1 & 4.5 & 2.5 & 2.6 \\
\hline & 305 & 1.6 & 0.5 & 1 & 3.5 & 1.5 & 3.6 \\
\hline & 305 & 1.8 & 0.7 & 1 & 4 & 1.6 & 3.1 \\
\hline Panel C: Germany & Obc & Mean & Std Dou & Min & Moy & Modian & \multirow{2}{*}{ Kurtosis } \\
\hline & & & & & & & \\
\hline Limited Access to Finance & 168 & 2.2 & 1 & 1 & 4 & 2 & 1.9 \\
\hline Weak Infrastructure & 168 & 1.4 & 0.5 & 1 & 4 & 1.3 & 9.9 \\
\hline Weak Law and Order & 168 & 1.7 & 0.6 & 1 & 3.7 & 1.5 & 3.9 \\
\hline Red Tape & 168 & 2.1 & 0.7 & 1 & 4 & 2 & 2.7 \\
\hline
\end{tabular}

Table to be continued. 
Table 4 (continued): Descriptive Statistics of Obstacles to Firm Operations

\begin{tabular}{|c|c|c|c|c|c|c|c|}
\hline Panel D: Ireland & Obs. & Mean & Std. Dev. & Min & Max & Median & Kurtosis \\
\hline $\begin{array}{r}\text { Limited Access to Finance } \\
\text { Weak Infrastructure } \\
\text { Weak Law and Order } \\
\text { Red Tape }\end{array}$ & $\begin{array}{l}140 \\
140 \\
140 \\
140\end{array}$ & $\begin{array}{l}1.9 \\
1.7 \\
1.6 \\
1.8\end{array}$ & $\begin{array}{r}1 \\
0.8 \\
0.6 \\
0.8\end{array}$ & $\begin{array}{l}1 \\
1 \\
1 \\
1\end{array}$ & $\begin{array}{l}4 \\
4 \\
4 \\
4\end{array}$ & $\begin{array}{l}1.5 \\
1.5 \\
1.5 \\
1.7\end{array}$ & $\begin{array}{l}2.3 \\
2.9 \\
5.8 \\
3.3\end{array}$ \\
\hline Panel E: South Korea & Obs. & Mean & Std. Dev. & Min & $\operatorname{Max}$ & Median & Kurtosis \\
\hline $\begin{array}{r}\text { Limited Access to Finance } \\
\text { Weak Infrastructure } \\
\text { Weak Law and Order } \\
\text { Red Tape }\end{array}$ & $\begin{array}{l}177 \\
176 \\
176 \\
177\end{array}$ & $\begin{array}{r}2 \\
1.5 \\
1.9 \\
1.7\end{array}$ & $\begin{array}{l}1.1 \\
0.8 \\
0.7 \\
0.8\end{array}$ & $\begin{array}{l}1 \\
1 \\
1 \\
1\end{array}$ & $\begin{array}{l}4 \\
4 \\
4 \\
4\end{array}$ & $\begin{array}{r}1.5 \\
1 \\
2 \\
1.5\end{array}$ & $\begin{array}{l}2.1 \\
4.5 \\
2.9 \\
3.3\end{array}$ \\
\hline Panel F: Spain & Obs. & Mean & Std. Dev. & Min & $\operatorname{Max}$ & Median & Kurtosis \\
\hline $\begin{array}{r}\text { Limited Access to Finance } \\
\text { Weak Infrastructure } \\
\text { Weak Law and Order } \\
\text { Red Tape }\end{array}$ & $\begin{array}{l}114 \\
114 \\
114 \\
114\end{array}$ & $\begin{array}{r}2.3 \\
1.8 \\
1.9 \\
2\end{array}$ & $\begin{array}{l}1 \\
0.9 \\
0.9 \\
0.9\end{array}$ & $\begin{array}{l}1 \\
1 \\
1 \\
1\end{array}$ & $\begin{array}{r}4 \\
3.8 \\
4 \\
4\end{array}$ & $\begin{array}{r}2 \\
1.5 \\
1.6 \\
1.7\end{array}$ & $\begin{array}{r}1.8 \\
2.9 \\
3 \\
2.5\end{array}$ \\
\hline
\end{tabular}

Notes: We use 2005 data for Botswana, Burundi, Tanzania, and Uganda, 2006 data for Kenya, South Africa, Ghana, Nigeria, Zambia, and Senegal, and 2005 data for Germany, Ireland, South Korea, and Spain. We average answers to questions about obstacles into four groups: Limited Access to Finance, Weak Infrastructure, Weak Law and Order, and Red Tape. The basic obstacle measure is the response to the question "Do you think that X presents any obstacle to the current operations of your establishment?" where X represents various questions whose answers are averaged into these four groups. Answers vary between 1 (no obstacle), 2 (minor obstacle), 3 (moderate obstacle), 4 (major obstacle), and 5 (very severe obstacle). Weak Infrastructure is composed of the following Xs: "Electricity," "Telecommunications," "Transportation," and "Access to Land." Red Tape is composed of the following Xs: "Tax Rates," "Tax Administration," "Customs and Trade Regulations," "Labor Regulations," and "Business Licensing and Permits." Weak Law and Order is composed of the following Xs: "Functioning of the Courts," "Political Instability," "Corruption," "Macroeconomic Instability," "Crime, Theft and Disorder," and "Practices of Competitors in the Informal Sector." Limited Access to Finance is a stand alone question which represents a single X. Weak Law and Order and Red Tape are coded such that higher values correspond to less law and order and more red tape. 
Table 5: Firm-Level Determinants of Misallocation

\begin{tabular}{|c|c|c|c|c|c|c|c|}
\hline Dependent Variable: Log MPK & (Africa) & (Africa) & (Africa) & (Africa) & (India) & (S. Korea) & (Europe) \\
\hline Limited Access to Finance & $\begin{array}{r}4.5 \\
(18)\end{array}$ & $\begin{array}{r}3.2 \\
(1.5)\end{array}$ & $\begin{array}{r}2.6 \\
(1.6)\end{array}$ & $\begin{array}{r}4.9^{* *} \\
(2.4)\end{array}$ & $\begin{array}{r}2.3 \\
(0.5)\end{array}$ & 13.4 & $\begin{array}{r}-5.3 \\
(-0.8)\end{array}$ \\
\hline Weak Infrastructure & 6.1 & 5.4 & $\begin{array}{r}6.1 \\
(1.2)\end{array}$ & $\begin{array}{r}12.0^{* * *} \\
(2.4)\end{array}$ & $\begin{array}{r}16.9^{* *} \\
(2.3)\end{array}$ & $\begin{array}{r}8.5 \\
(0.9)\end{array}$ & $\begin{array}{l}-22.1 \\
(-16)\end{array}$ \\
\hline Weak Law and Order & $\begin{array}{l}-9.3^{* *} \\
(-2.5)\end{array}$ & $\begin{array}{l}-8.6^{*} \\
(-2.2)\end{array}$ & $\begin{array}{l}-8.2^{*} \\
(-2.2)\end{array}$ & $\begin{array}{r}-4.8 \\
(-0.8)\end{array}$ & $\begin{array}{l}-11.8 \\
(-1.3)\end{array}$ & $\begin{array}{r}-2.8 \\
(-0.2)\end{array}$ & $\begin{array}{l}-0.5 \\
(-0.0)\end{array}$ \\
\hline Red Tape & $\begin{array}{l}-7.4^{*} \\
(-1.9)\end{array}$ & $\begin{array}{r}-4.9 \\
(-1.4)\end{array}$ & $\begin{array}{l}-6.4^{*} \\
(-1.9)\end{array}$ & $\begin{array}{r}-15.1^{* * * *} \\
(-4.1)\end{array}$ & $\begin{array}{r}11.8^{* * * *} \\
(3.2)\end{array}$ & $\begin{array}{l}-13.6 \\
(-0.4)\end{array}$ & $\begin{array}{r}18.2^{*} \\
(1.9)\end{array}$ \\
\hline Age & & & $\begin{array}{l}-0.2 \\
(-0.7)\end{array}$ & $\begin{array}{l}-0.4^{* *} \\
(-27)\end{array}$ & $\begin{array}{l}-0.2 \\
(-0.5)\end{array}$ & $\begin{array}{r}-0.9 \\
(-1.6)\end{array}$ & $\begin{array}{r}-0.2 \\
(-1.2)\end{array}$ \\
\hline Export & & & $\begin{array}{l}14.5 \\
(0.5)\end{array}$ & $\begin{array}{l}13.5 \\
(0.5)\end{array}$ & $\begin{array}{r}89.1^{* * * *} \\
(5.8)\end{array}$ & $\begin{array}{r}-9.5 \\
(-0.3)\end{array}$ & $\begin{array}{r}21.3 \\
(0.8)\end{array}$ \\
\hline Small & & & $\begin{array}{r}-16.0^{* * *} \\
(-3.4)\end{array}$ & $\begin{array}{r}-9.0 \\
(-1.3)\end{array}$ & $\begin{array}{r}-61.9^{* * * *} \\
(-6.9)\end{array}$ & $\begin{array}{l}-12.4 \\
(-1.0)\end{array}$ & $\begin{array}{r}-26.0^{*} \\
(-1.9)\end{array}$ \\
\hline Fin*Export & & & $\begin{array}{r}-24.8^{* *} \\
(-2.5)\end{array}$ & $\begin{array}{r}-23.6^{* *} \\
(-2.8)\end{array}$ & $\begin{array}{l}-15.0 \\
(-1.0)\end{array}$ & $\begin{array}{r}-50.4^{* *} \\
(-2.9)\end{array}$ & $\begin{array}{r}64.4^{* * *} \\
(5.3)\end{array}$ \\
\hline Inf*Export & & & $\begin{array}{r}3.9 \\
(0.2)\end{array}$ & $\begin{array}{r}-4.5 \\
(-0.2)\end{array}$ & $\begin{array}{r}45.6^{* * *} \\
(2.7)\end{array}$ & $\begin{array}{l}-32.2 \\
(-0.8)\end{array}$ & $\begin{array}{r}42.9 \\
(1.2)\end{array}$ \\
\hline Law*Export & & & $\begin{array}{r}4.4 \\
(0.2)\end{array}$ & $\begin{array}{l}-13.3 \\
(-0.8)\end{array}$ & $\begin{array}{r}3.8 \\
(0.3)\end{array}$ & $\begin{array}{l}-23.9 \\
(-0.6)\end{array}$ & $\begin{array}{r}-69.8 \\
(-1.5)\end{array}$ \\
\hline Red*Export & & & -3.3 & 11.3 & -23.6 & $84.9^{* *}$ & -53.3 \\
\hline Country effects & Yes & Yes & $\begin{array}{r}(-0.2) \\
\text { Yes }\end{array}$ & $\begin{array}{r}(0.5) \\
\text { No }\end{array}$ & $\begin{array}{r}(-0.8) \\
\text { No }\end{array}$ & $\begin{array}{r}(2.8) \\
\text { No }\end{array}$ & $\begin{array}{r}(-1.2) \\
\text { No }\end{array}$ \\
\hline Industry effects & No & Yes & Yes & Yes & Yes & Yes & Yes \\
\hline$\underset{N}{\operatorname{Adj} .} \mathrm{R}$ sq. & $\begin{array}{r}0.1 \\
3533\end{array}$ & $\begin{array}{r}0.1 \\
3533\end{array}$ & $\begin{array}{r}0.1 \\
3529\end{array}$ & $\begin{array}{r}0.0 \\
3529\end{array}$ & $\begin{array}{r}0.1 \\
1449\end{array}$ & $\begin{array}{r}-0.1 \\
141\end{array}$ & $\begin{array}{r}0.4 \\
362\end{array}$ \\
\hline
\end{tabular}

Notes: See notes to the previous tables for variable explanations. The interaction variables are constructed by the multiplication of $($ Export $-\overline{\text { Export }})$ with $(X-\bar{X})$ where $X$ refers to an obstacle group and $\bar{X}$ refers to the mean of the corresponding variable over all firms. Export is a dummy which indicates firms whose percentage of direct exports to total sales exceed 50. The Africa sample comprises Botswana, Burundi, Ghana, Kenya, Nigeria, Senegal, South Africa, Tanzania, Uganda, and Zambia. The Europe sample comprises Germany, Ireland and Spain. Standard errors are robust and t-statistics are reported in parentheses. $* * *, * *$, and $*$ indicate significance at the $1 \%, 5 \%$, and $10 \%$ levels, respectively. 
Table 6: Firm-Level Determinants of Misallocation

\begin{tabular}{|c|c|c|c|c|c|c|}
\hline Dependent Variable: Log HK-index & (Africa) & (Africa) & (Africa) & (Africa) & (India) & (Europe) \\
\hline Limited Access to Finance & $11.0^{* * *}$ & $8.6^{* * *}$ & $7.1^{* * *}$ & $10.8^{* * *}$ & 2.9 & -2.6 \\
\hline Weak Infrastructure & $\begin{array}{l}(3.5) \\
-2.6\end{array}$ & $\begin{array}{l}(3.4) \\
-2.7\end{array}$ & $\begin{array}{l}(4.2) \\
-2.4\end{array}$ & $\begin{array}{r}(4.6) \\
4.2\end{array}$ & $\begin{array}{r}(0.5) \\
3.9\end{array}$ & $\begin{array}{r}(-0.3) \\
-9.7\end{array}$ \\
\hline & $(-0.5)$ & $(-0.6)$ & $(-0.5)$ & $(0.9)$ & $(0.4)$ & $(-0.6)$ \\
\hline Weak Law and Order & -5.8 & -5.4 & -6.2 & -4.1 & -15.2 & -9.4 \\
\hline Red Tape & $\begin{array}{l}(-1.0) \\
-11.5^{*}\end{array}$ & $\begin{array}{r}-1.4) \\
-8.5\end{array}$ & $\begin{array}{r}-1.0) \\
-8.1\end{array}$ & $-24.9 * * *$ & $\begin{aligned} &(-1.5) \\
& 16.0^{* * *}\end{aligned}$ & $\begin{array}{r}(-1.2) \\
11.3\end{array}$ \\
\hline & $(-2.2)$ & $(-1.8)$ & $(-1.8)$ & $(-6.0)$ & $(3.4)$ & $(1.2)$ \\
\hline Age & & & $\begin{array}{r}-0.0 \\
(-0.0)\end{array}$ & $\begin{array}{r}-0.3 \\
(-1.4)\end{array}$ & $\begin{array}{l}-0.1 \\
(-0.3)\end{array}$ & $\begin{array}{r}0.0 \\
(0.1)\end{array}$ \\
\hline Export & & & 11.5 & 12.8 & $96.4^{* * *}$ & 6.4 \\
\hline & & & $(0.4)$ & $(0.6)$ & $(3.3)$ & $(0.3)$ \\
\hline Small & & & -10.3 & -1.4 & $-60.0^{* * *}$ & 3.7 \\
\hline Fin*Export & & & $\begin{array}{l}(-1.3) \\
-35.1^{*}\end{array}$ & $\begin{aligned}(-0.1) \\
-29.1 * *\end{aligned}$ & $\begin{array}{r}(-7.2) \\
-6.6\end{array}$ & $\begin{aligned}(0.4) \\
-23.4\end{aligned}$ \\
\hline & & & $(-2.2)$ & $(-3.0)$ & $(-0.4)$ & $(-1.2)$ \\
\hline Inf*Export & & & -3.7 & -13.8 & 25.5 & 20.2 \\
\hline & & & $(-0.2)$ & $(-0.7)$ & $(1.0)$ & $(0.3)$ \\
\hline Law*Export & & & -14.7 & $-41.0^{* *}$ & 32.9 & $\begin{aligned} 7.3 \\
(0.1)\end{aligned}$ \\
\hline Red*Export & & & 28.0 & $42.3^{* *}$ & -49.2 & -14.7 \\
\hline Country effects & Yes & Yes & $\begin{array}{r}(1.0) \\
\text { Yes }\end{array}$ & $\begin{array}{r}(2.4) \\
\text { No }\end{array}$ & $\begin{array}{r}(-1.2) \\
\text { No }\end{array}$ & $\begin{array}{r}(-0.3) \\
\text { Yes }\end{array}$ \\
\hline Industry effects & No & Yes & Yes & Yes & Yes & Yes \\
\hline$\underset{N}{A d j . ~ R ~ s q . ~}$ & $\begin{array}{r}0.1 \\
3539\end{array}$ & $\begin{array}{r}0.2 \\
3539\end{array}$ & $\begin{array}{r}0.2 \\
3535\end{array}$ & $\begin{array}{r}0.1 \\
3535\end{array}$ & $\begin{array}{r}0.1 \\
1467\end{array}$ & $\begin{array}{r}-0.0 \\
219\end{array}$ \\
\hline
\end{tabular}

Notes: See notes to the previous tables for variable explanations. The interaction variables are constructed by the multiplication of $($ Export $-\overline{\text { Export }})$ with $(X-\bar{X})$ where $X$ refers to an obstacle group and $\bar{X}$ refers to the mean of the corresponding variable over all firms. Export is a dummy which indicates firms with percentage of direct exports to total sales greater than 50. The Africa sample comprises Botswana, Burundi, Ghana, Kenya, Nigeria, Senegal, South Africa, Tanzania, Uganda, and Zambia. The Europe sample comprises Ireland and Spain. Because German and South Korean firms are not asked to provide information on total cost of labor, the HK-index measure can not be calculated. Standard errors are robust and t-statistics are reported in parentheses. ***, **, and * indicate significance at the $1 \%, 5 \%$, and $10 \%$ levels, respectively. 

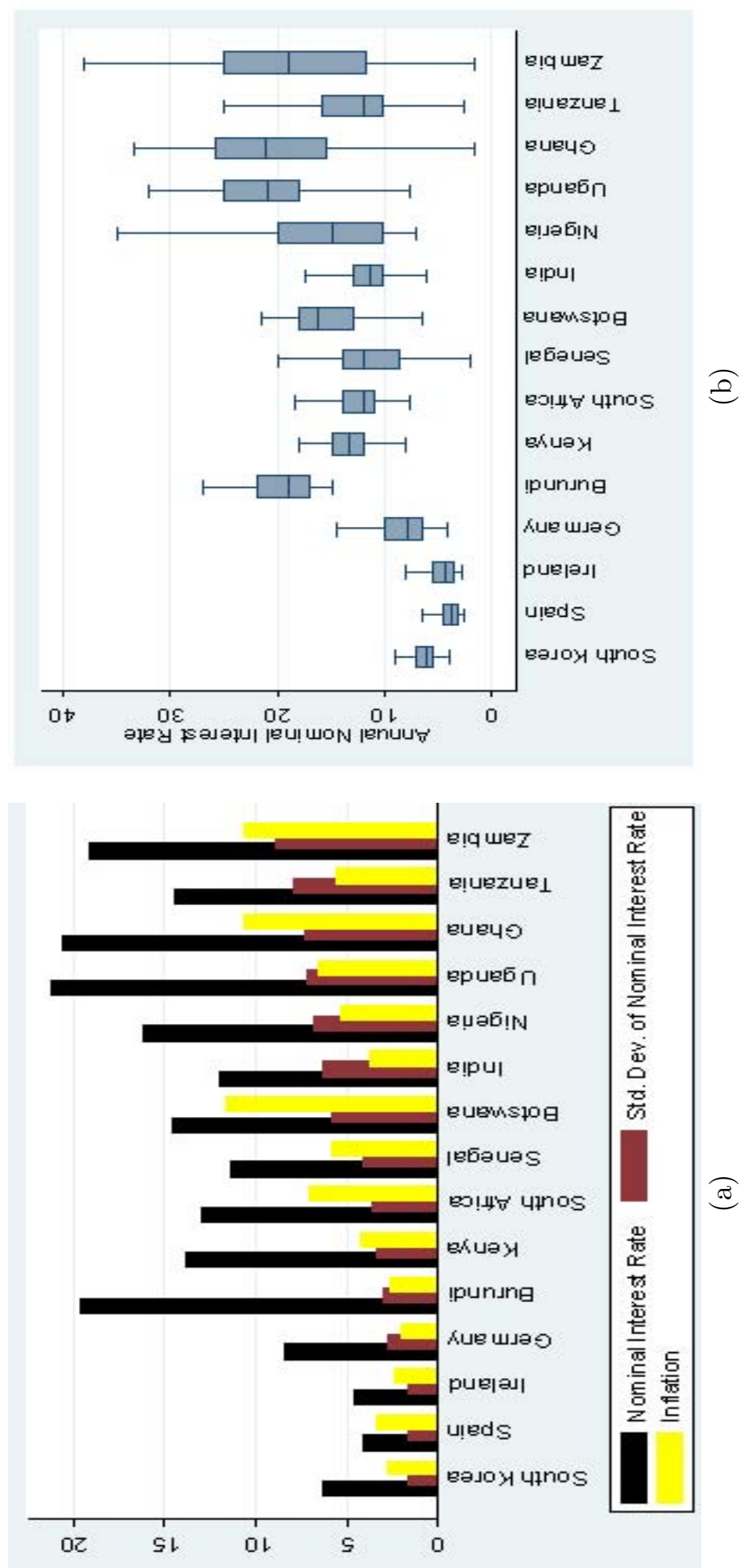

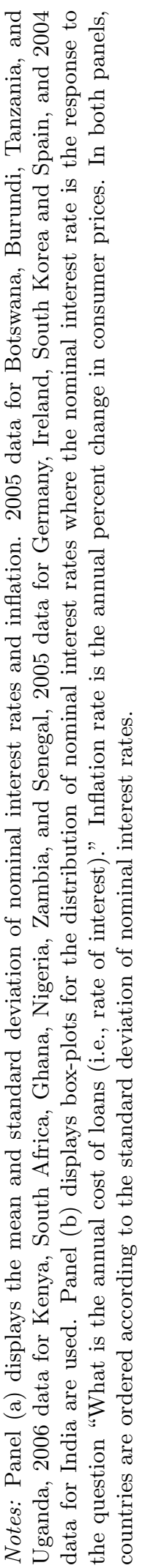



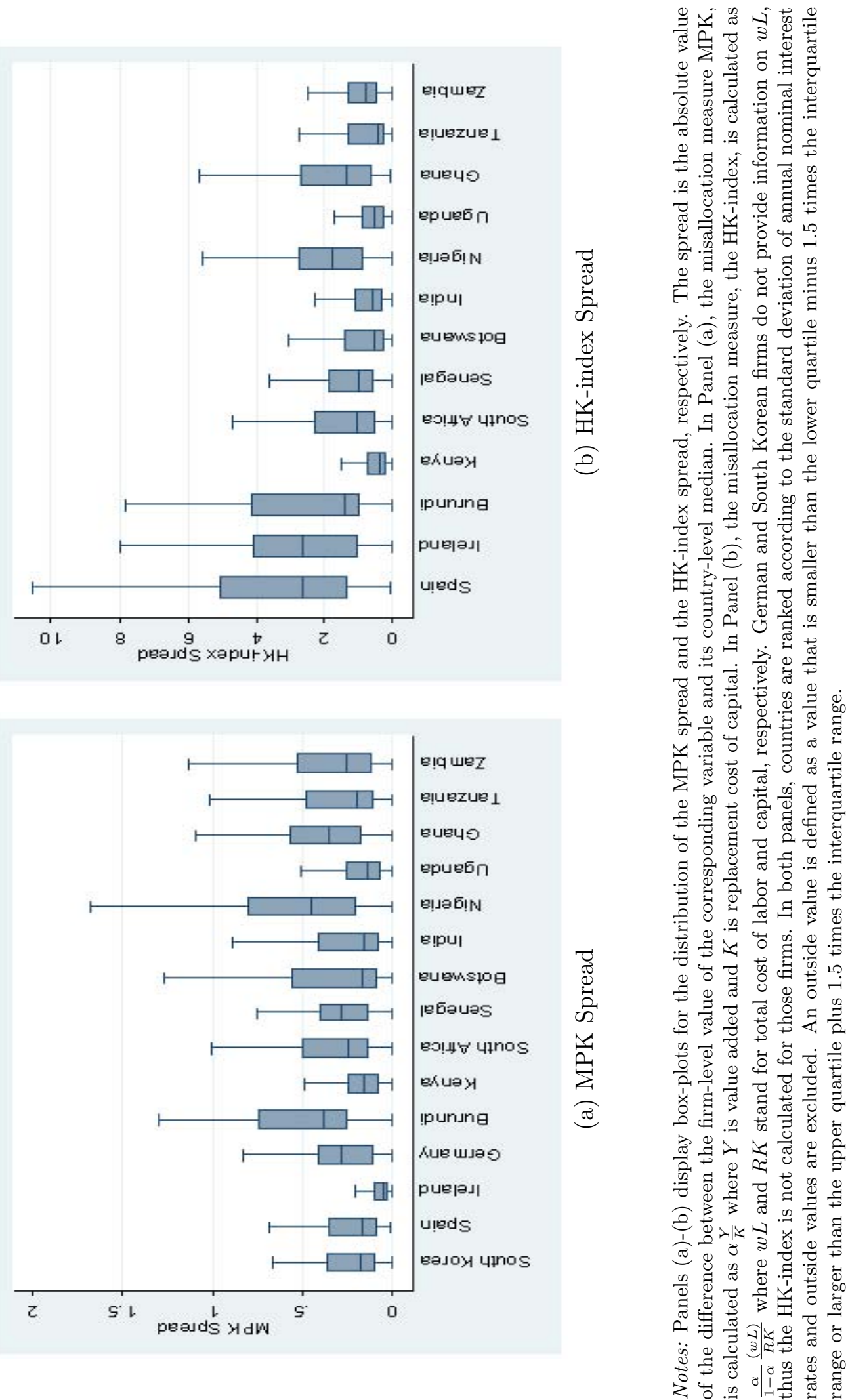


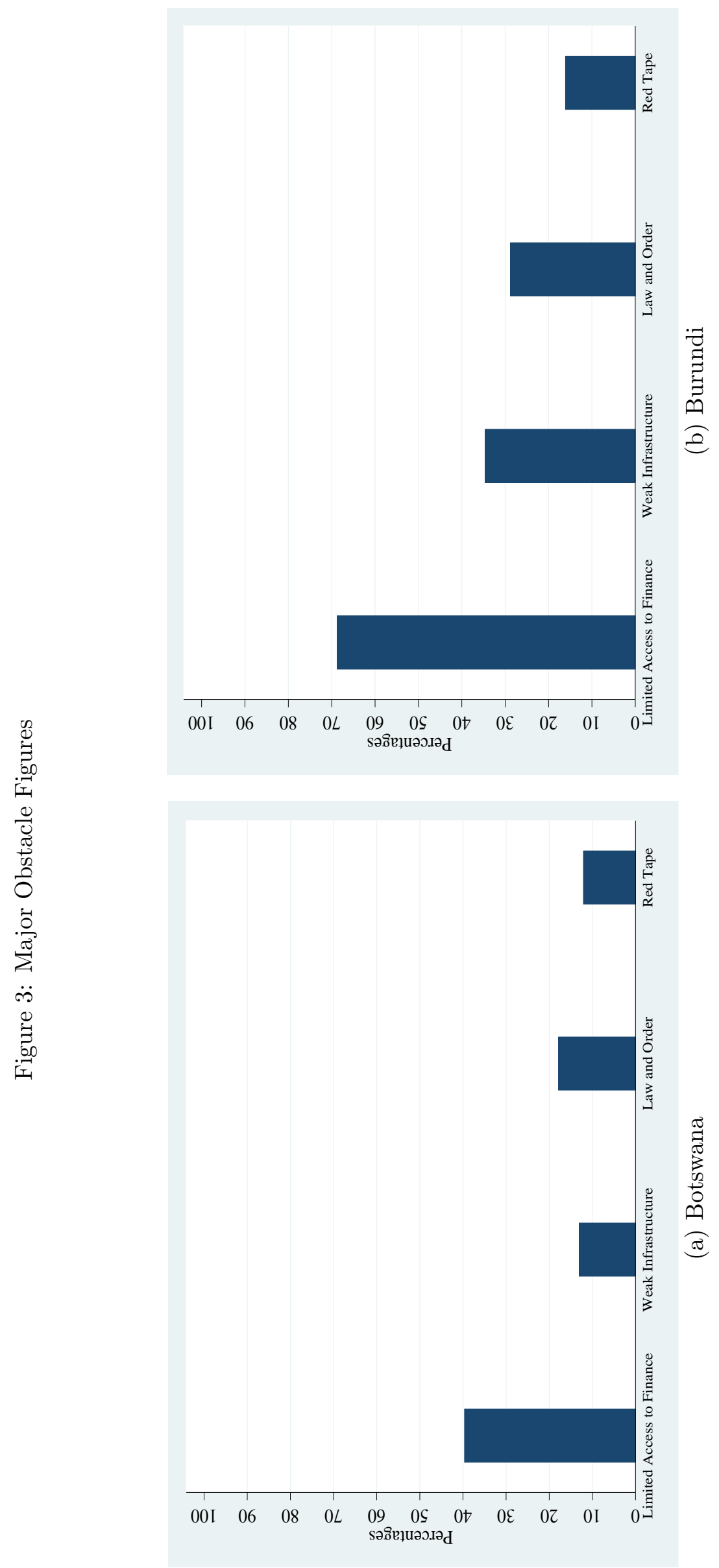

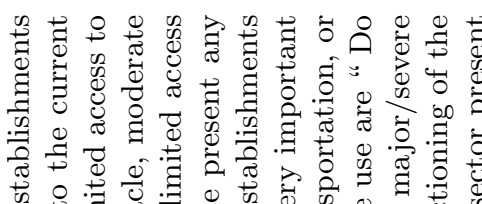

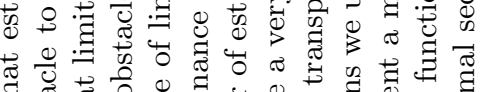

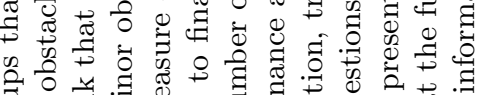

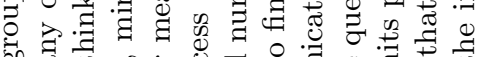
क人

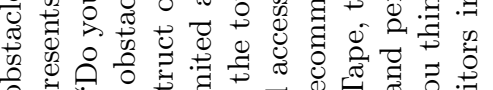

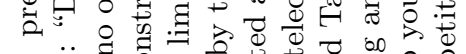

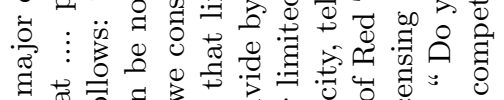

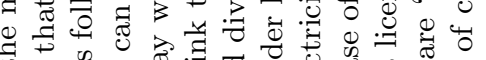

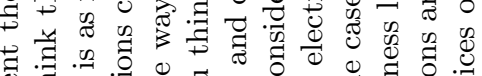

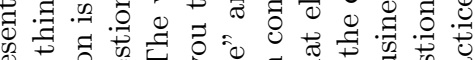

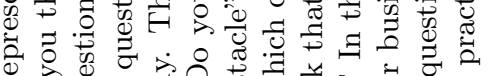

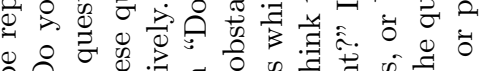

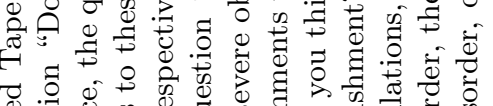

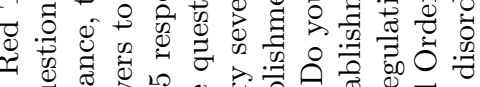

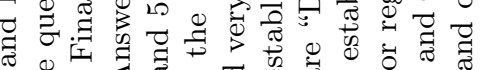

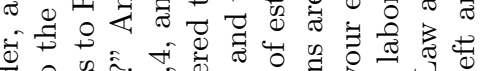
\&。 品

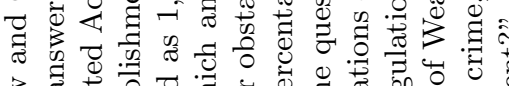

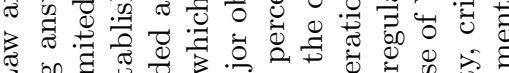

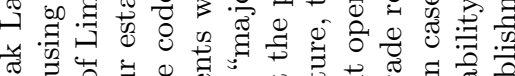

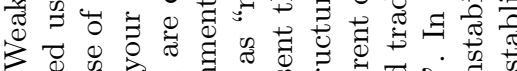
s

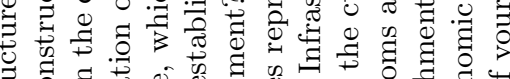

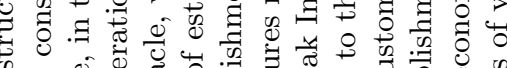

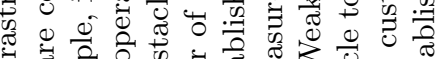
娄

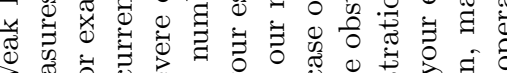

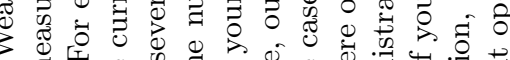
8 政.

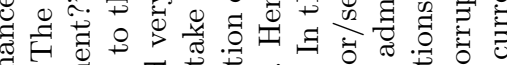

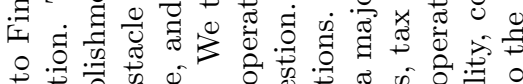

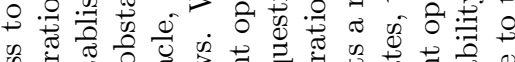

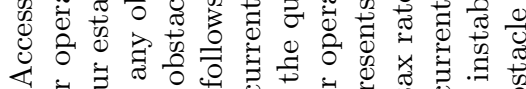

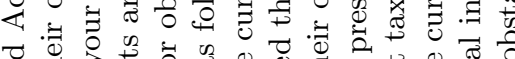

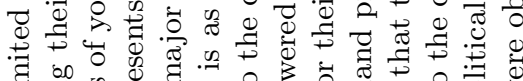

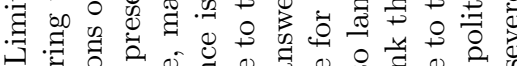

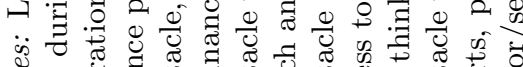

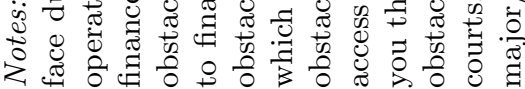




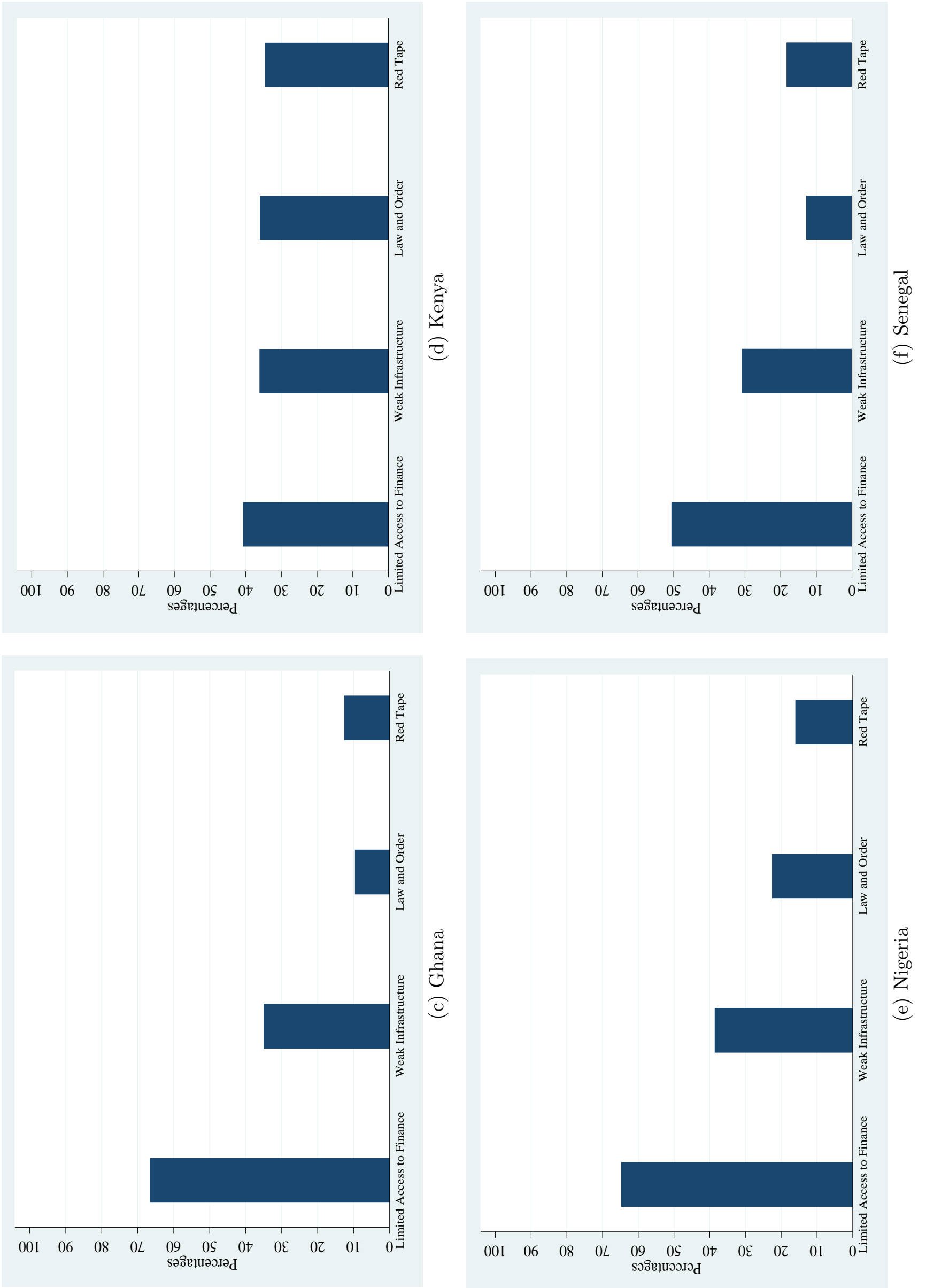

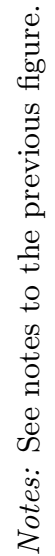



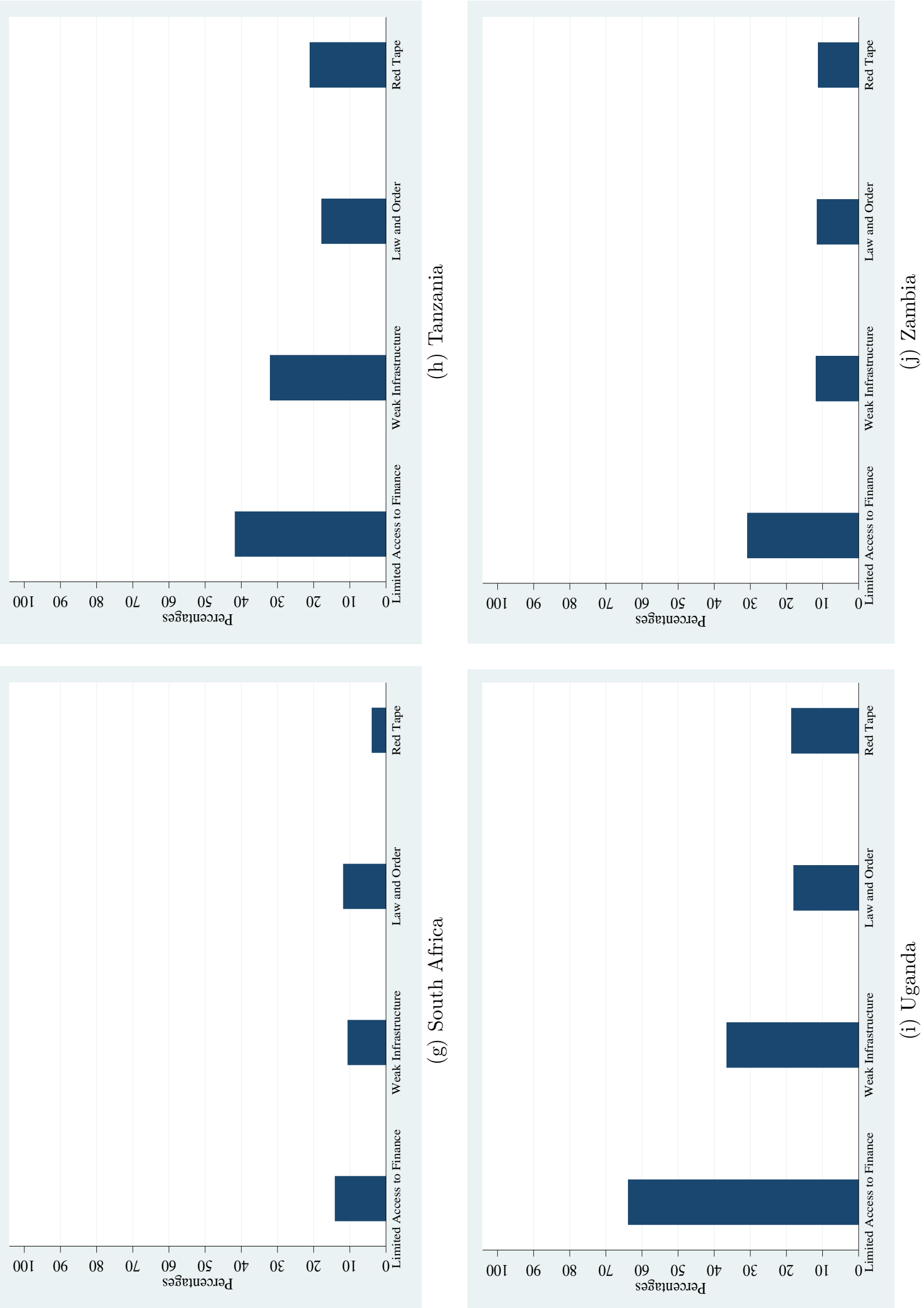

0
0
0
0
0
0
0
0
0
0
0
0
0
0
0
0
0
0
0
0
0
0
0
09
0
0
$z$ 

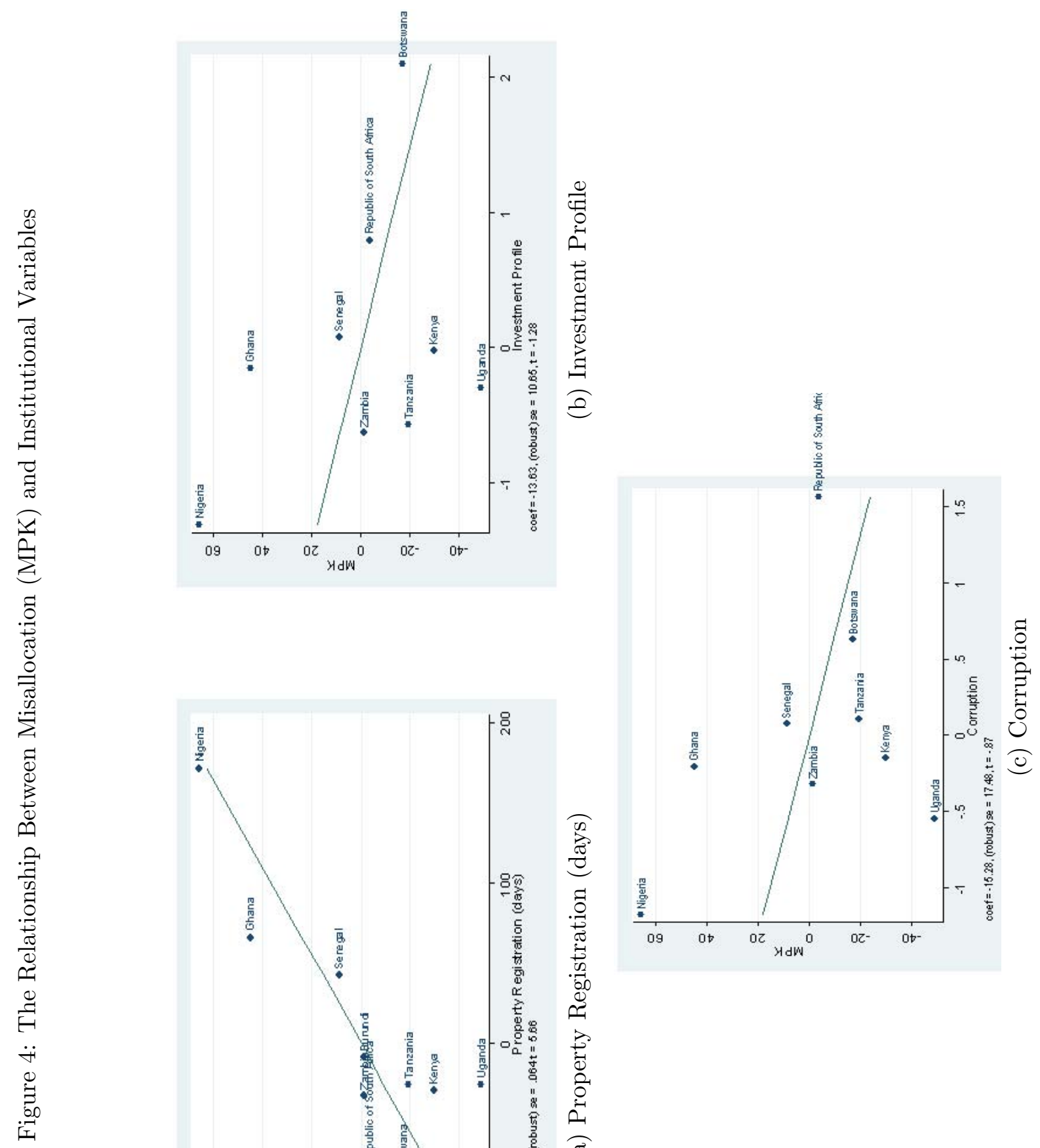

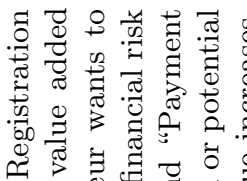

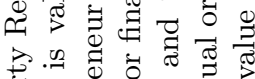

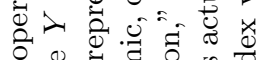

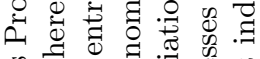

कृ

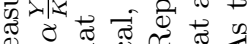

ठ

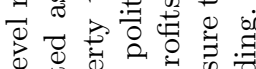

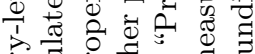

$=\overrightarrow{0}=$

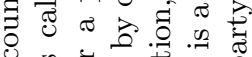

8 .

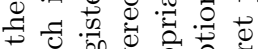

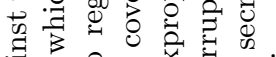

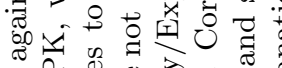

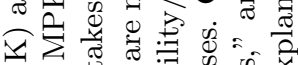

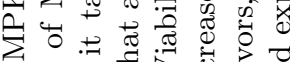

的沙

$\therefore 0$ 可

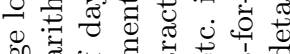

क्ष

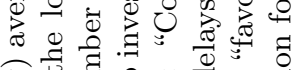

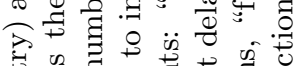

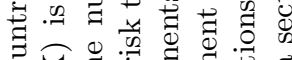

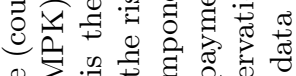

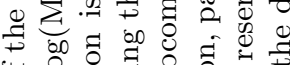

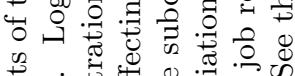

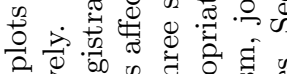

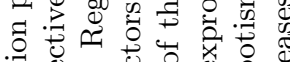

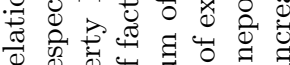

0 过

ठ

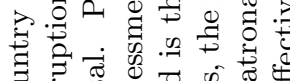

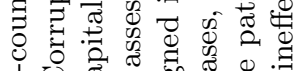

b

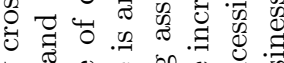

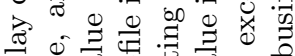

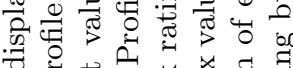

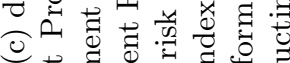

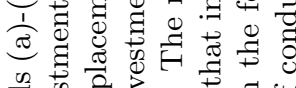

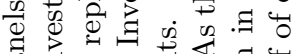

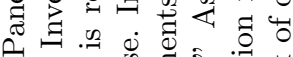

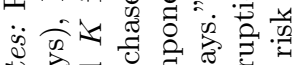

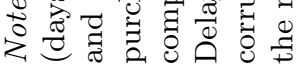




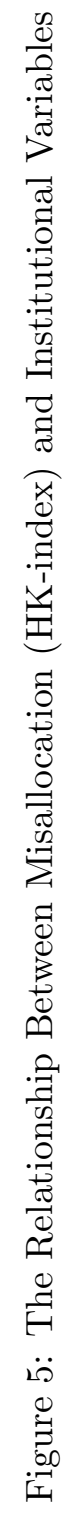

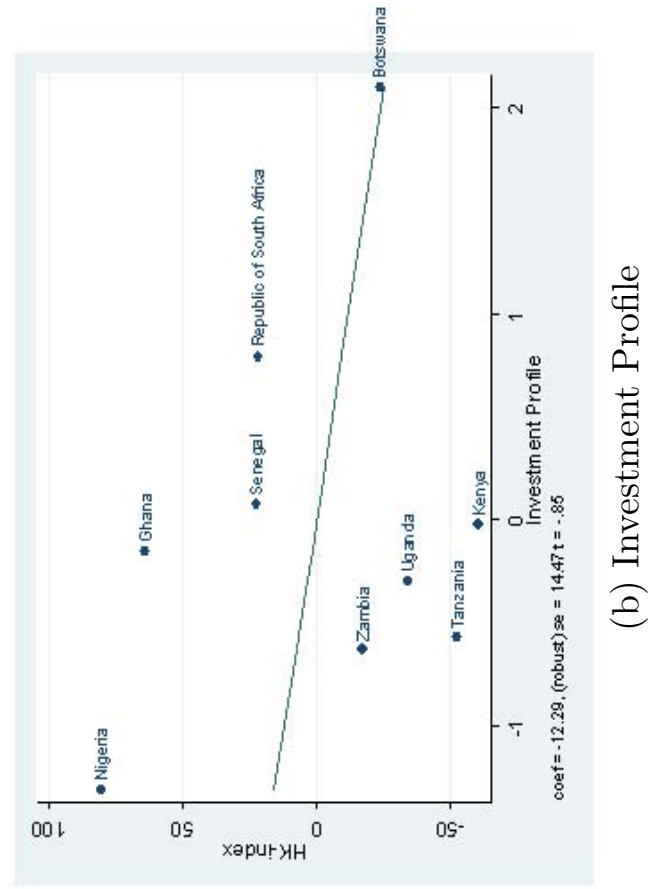

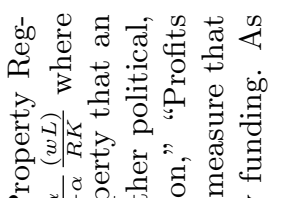

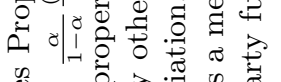

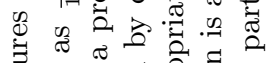
ఫ్

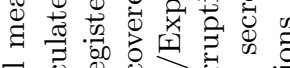
式 忌

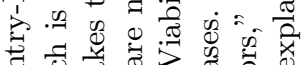

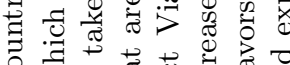
○ Ð

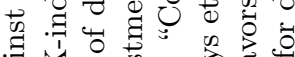
. ช० I

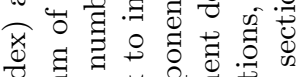

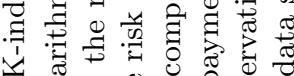

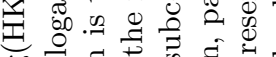

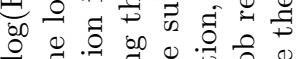

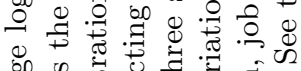

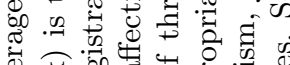

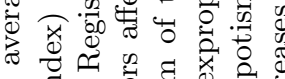

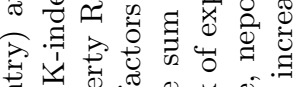

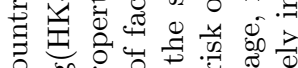

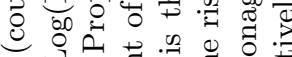

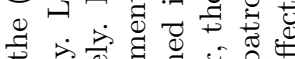

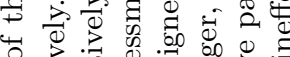

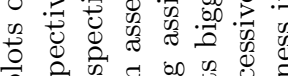

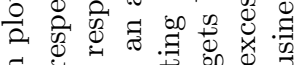

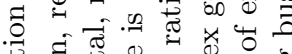

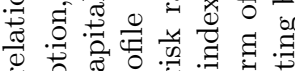
苛 记范苛

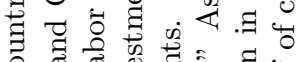

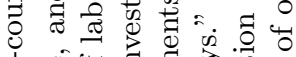

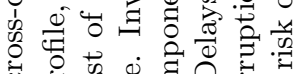
பी

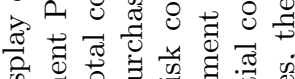

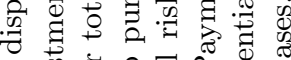
(仓)

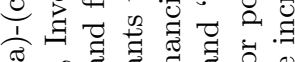

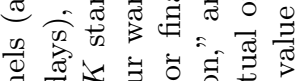

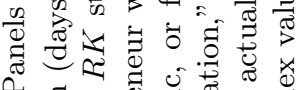

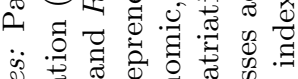

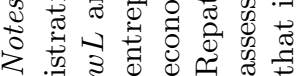

